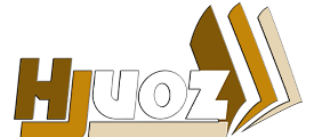

hjuoz.uoz.edu.krd p-ISSN: 2664-4673 e-ISSN: $2664-468$
كَوّارا زانستيّن مروّقايهتى يا زانكوّيا زاخوّ

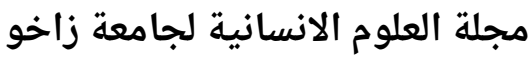

Humanities Journal of University of Zakho (HJUOZ)

Vol. 6, No. 4, pp. 927-947, December-2018

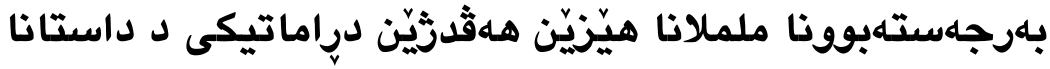 "شيَخيّ سهنعان" يا (فهقيى ن تهيران) دا ـ ب نموونهيا جوريّن

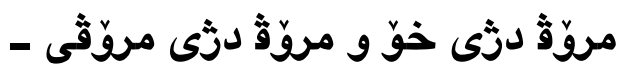 \\ شثان قاسم حسن 1* و عبدالله عزيز خالد (ئاكرين) 2

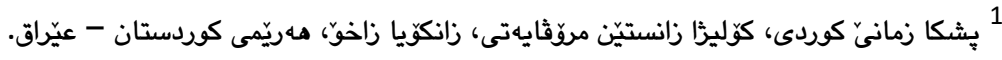

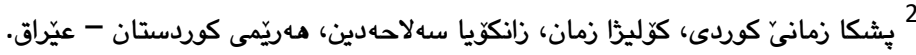

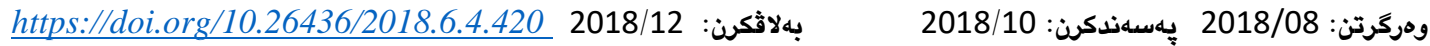

يوّخته:

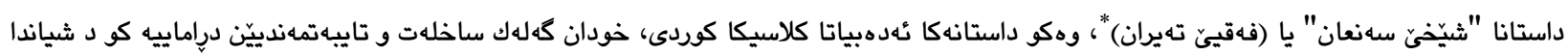

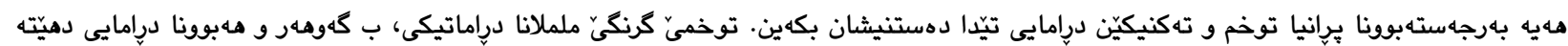

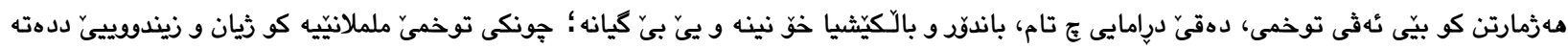

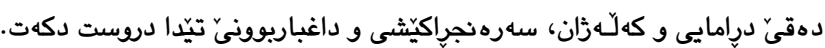

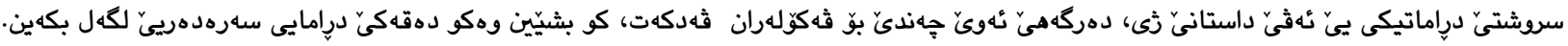

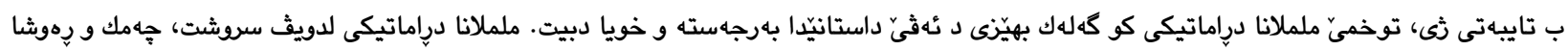

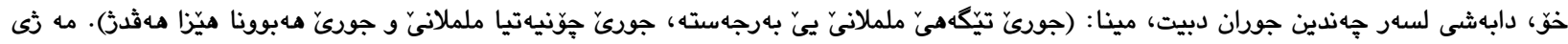

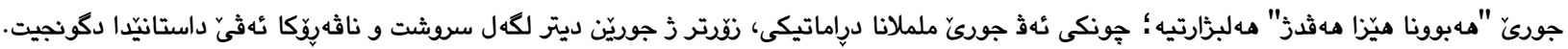

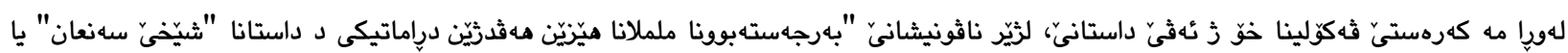

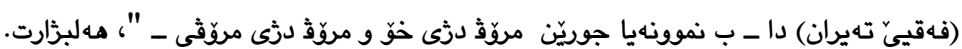

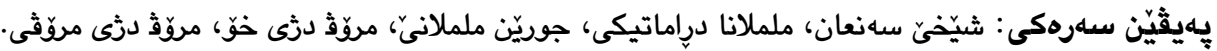
كرنكيا ليّكولينكرنا ئهثى بابهتى د وكيّ جهنديّدايه، كو داستانا

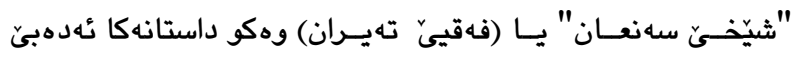
كهثني كوردى، خودان كهله بنهاما و تاييهتمهندييّن دراماتيكيه، كو

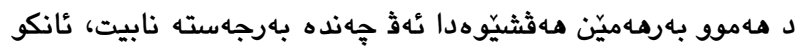

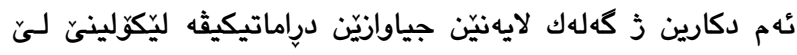

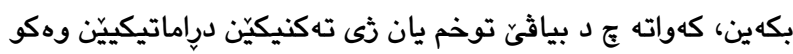

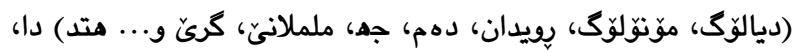
وهكو دهقهي بهيَزيّ درامايى سهرهدهرييّ لكهل بكهين و ئهفئ

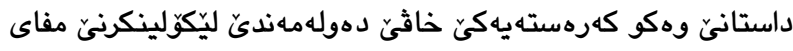

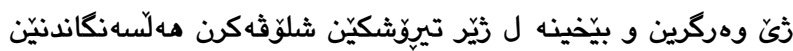
زانستى - ثئه كاديمى.

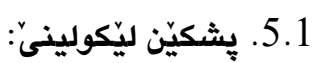

زبلى بِيشهكى و ئه نجامان، ثهكولينا مه جهاند تهوهر و سهرهبابهتان

$$
\begin{aligned}
& \text { بخوهثه دكريت، كو ب ئه ثيى شيّهييّ ل خواريّنه: }
\end{aligned}
$$

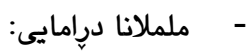

\section{1. بِيشنهى}

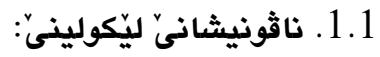

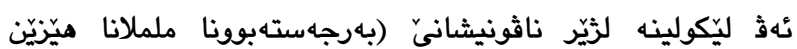

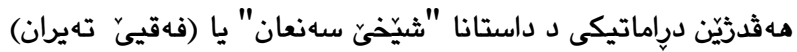

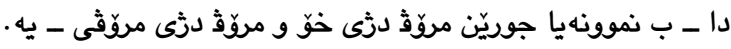

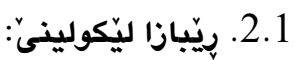

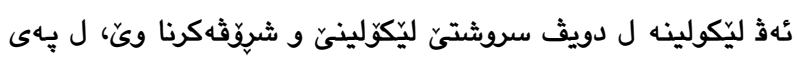
ريّبازا وهسفى - شرِوَه كارى هاتيه ئه نجامدان.

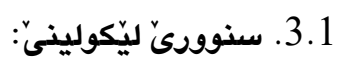

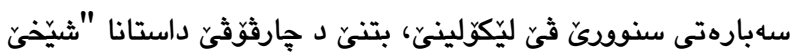
سهنعان" يا (فهقيى تهيران) دايه.

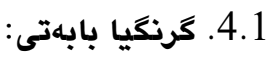




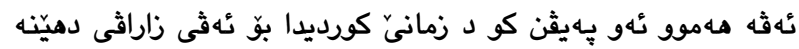

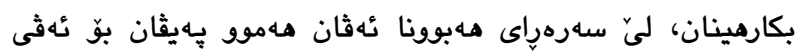

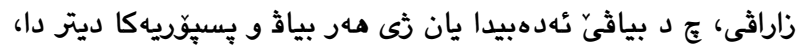

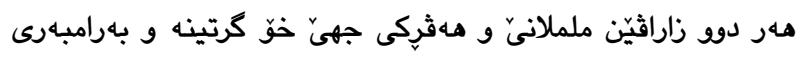

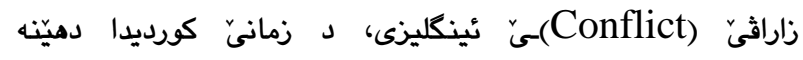

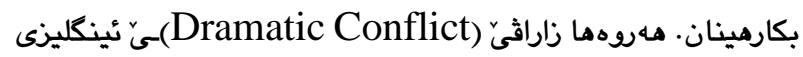

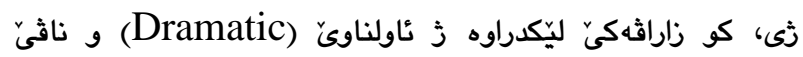
(ميّكدهيّت و بهرامبهرى وى زارافى مه د زمانيّ كورديدا (Conflict) (ململانا دراماتيكى) هديه.

\section{2. جههمكيّ ململانى و ململانا دراماتيكى:}

بهرى كو ئهم باس ل جهمكى ململانا دراماتيكى بكهين، ئهكهر

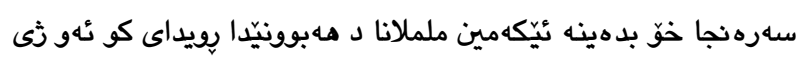

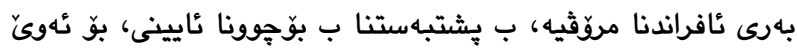

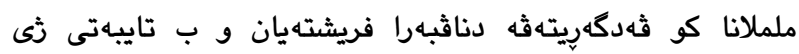

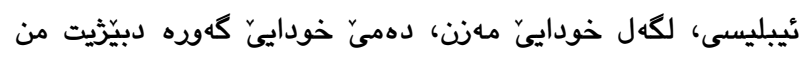

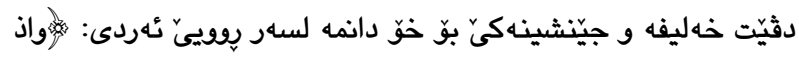
قال ريك للملئكة اني جاعل في الارض خليفة قالوا اتجعل فيها من يفسد

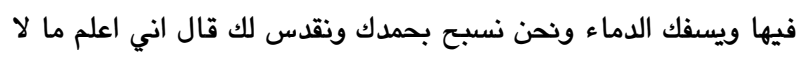

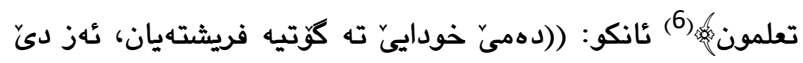

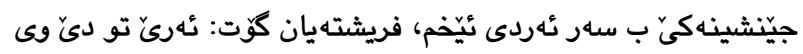

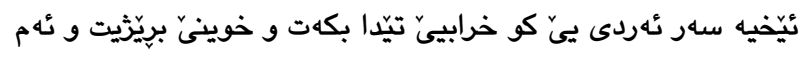

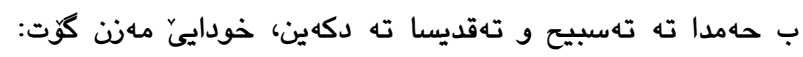

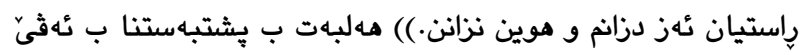

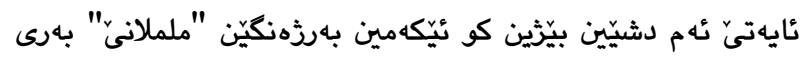

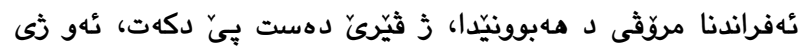

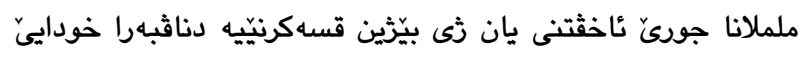

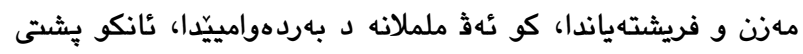

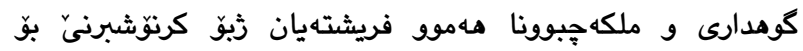

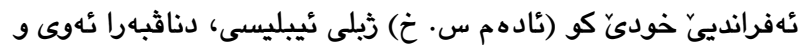

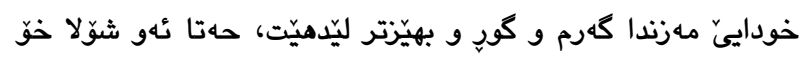

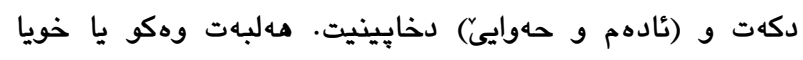

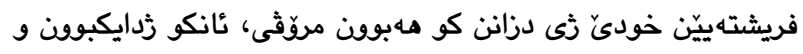

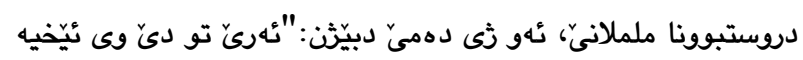

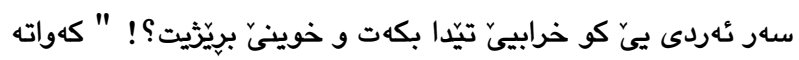

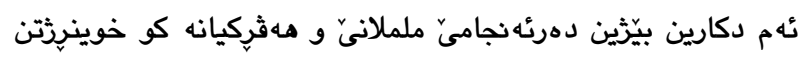

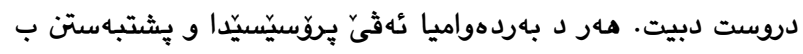

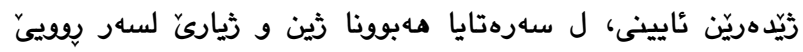

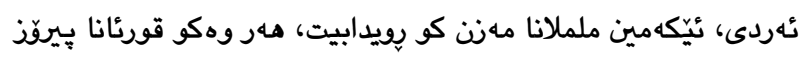

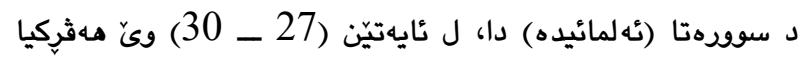

- بـهيث و زاراث

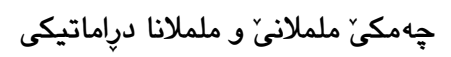

بِيَّاسيّن ململانا دراماتيكى

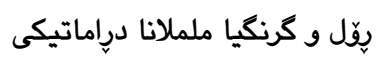

جوريّن ململانا دراماتيكى وني

دابه شبوونا ململانا دراماتيكى لدويث مهبوونا هيّزا هـثدرث:

ململانا مروّق دثى خوّ،

ململانا مروّة درَى مروَقىى.

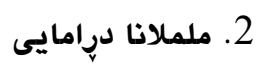

ململانيّ وهكو توخمهكيّ ههستيار و خودان باندوّ د ناثا ددقيَن دراماييدا، خودان كارتيكرنهكا كهودهيه لسهر توخم و تهكنيكين

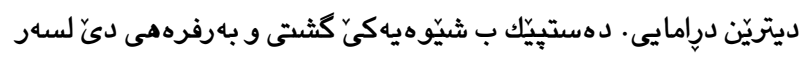

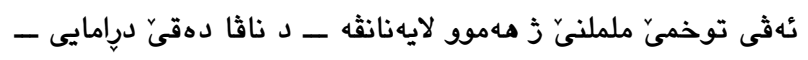

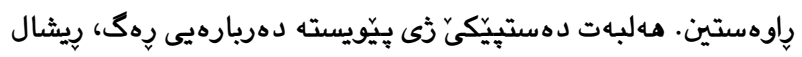

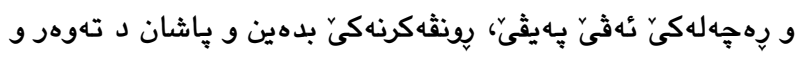

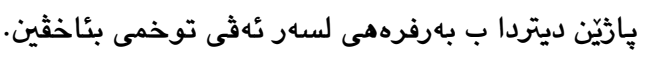

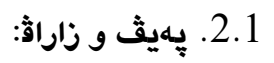

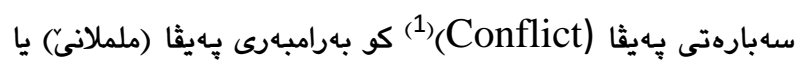

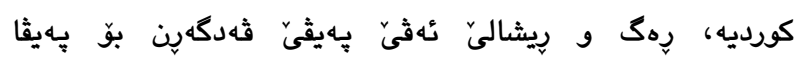

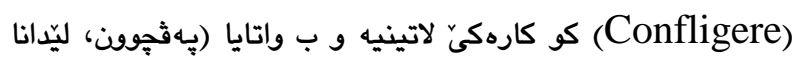

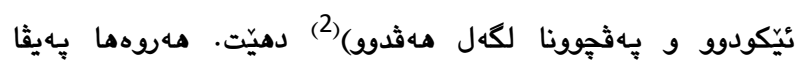
هندهك واتاييّن دى ثى ددهت، كو د هنده زمانيّن (Conflict)

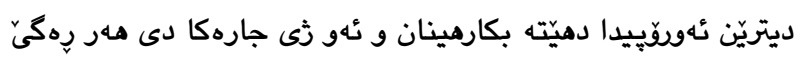

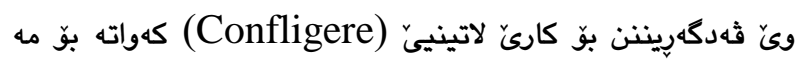

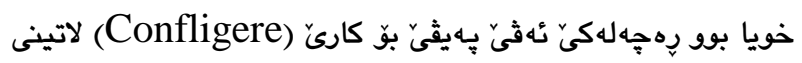

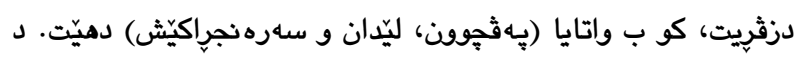

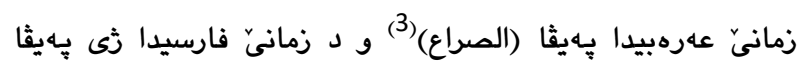

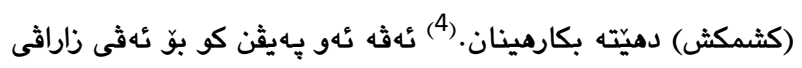
د ائهان زماناندا دمينّه بكارهينان.

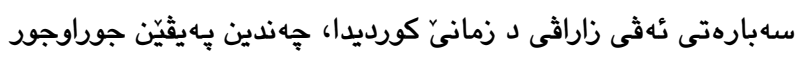

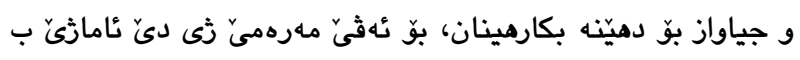

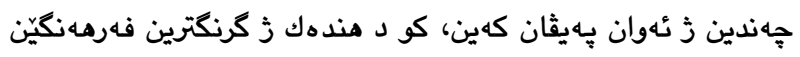

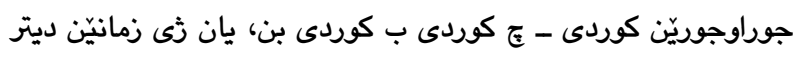

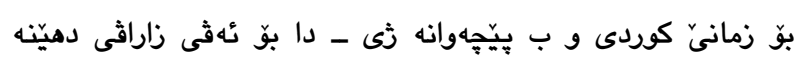

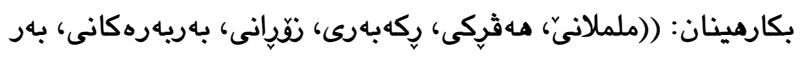

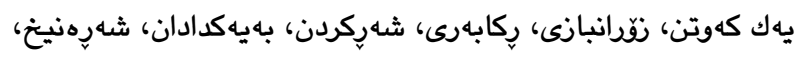

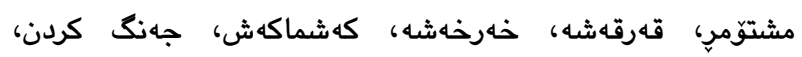

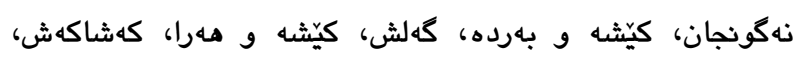

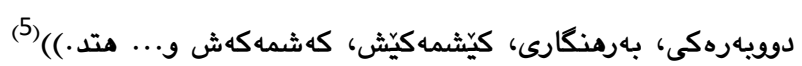




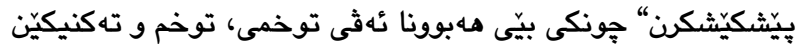

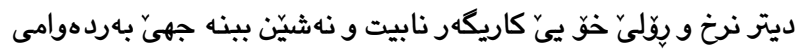

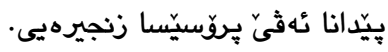

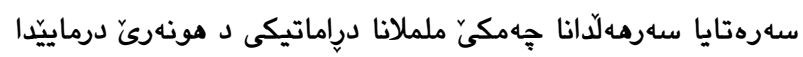

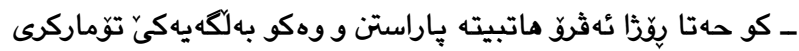

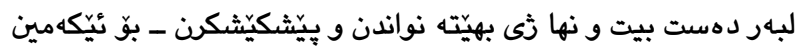

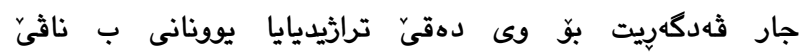

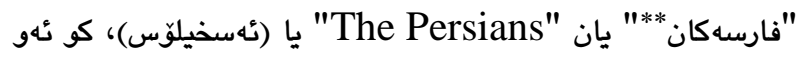

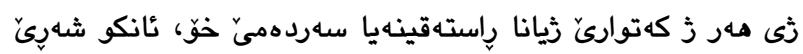

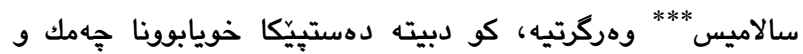

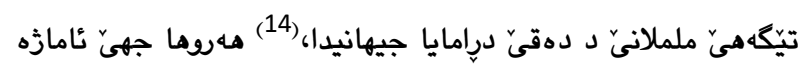

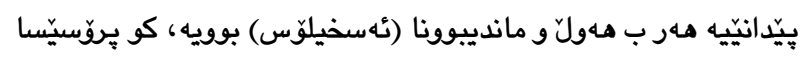

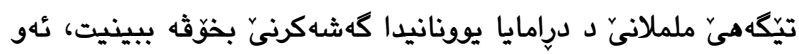

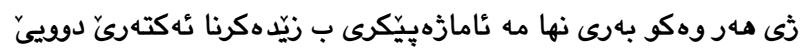

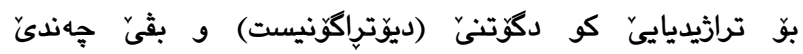

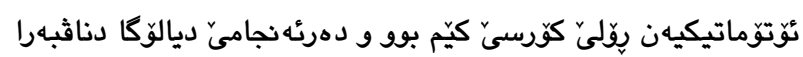

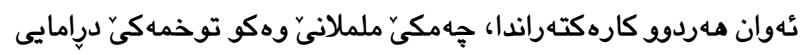

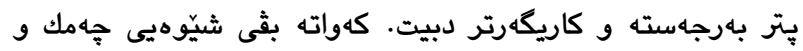
تيّكه هي ململانا دراماتيكى بهره بهره و لدويث قوّناغيّن جوراوجوريّن

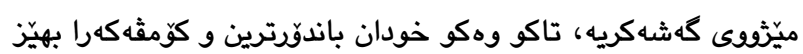
و مهستيارا هـهوو توخم و تهكنيكيّن ديتريَن درامايى ليّ بهيّت.

\section{3. يِيّناسيْن ململانا دراماتيكى :}

بحّ كومان ململانىّ وهكو توخمهكي كاريكهر د ئهدهبياتيّدا ب كثتى

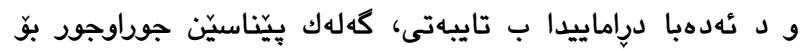

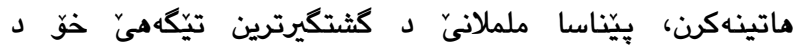

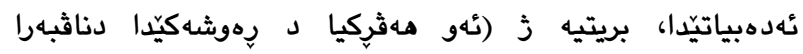

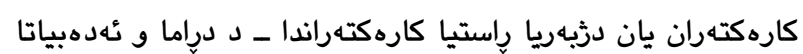

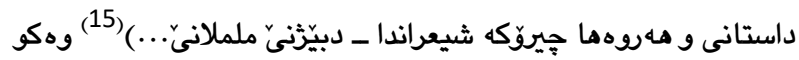

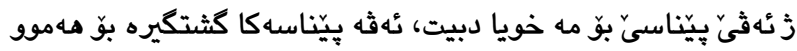

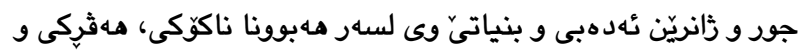

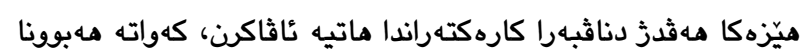

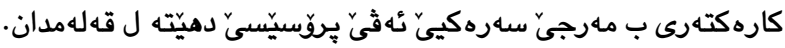

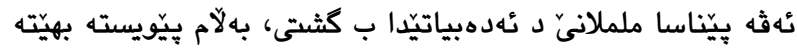

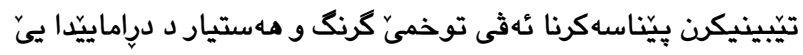
جياوازه ز مهردوو جوريّن ديتريّن ئهدهبى، ئانكو ئهدهبياتا داستانى حردي

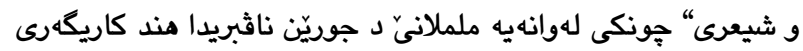

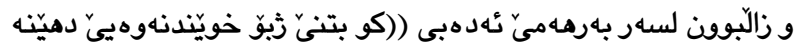
بهرهـثكن، تاك رهههندانهترن ب بهراورد لكهل دراماييّ يا كو خودان

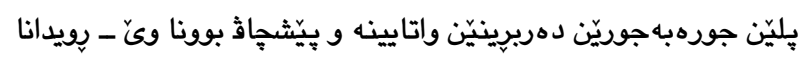

دناثبهرا كوريِن ئادهم (س. خ) قابيل (قائن: خاوهندار) و مابيل

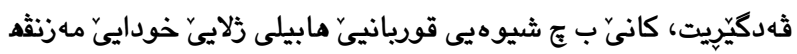

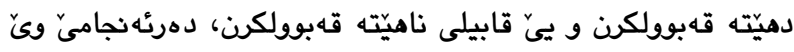

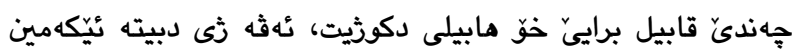

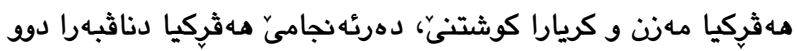

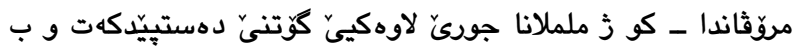
ململانا لاوهكيا جهستهيى ب داوى دبيت.- مرون

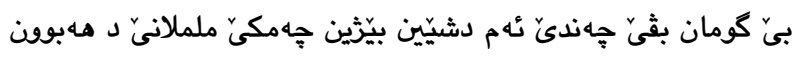

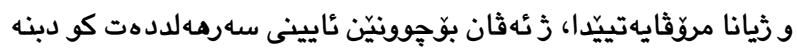

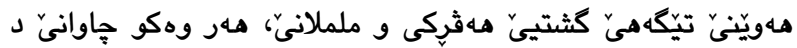

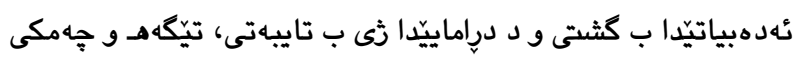

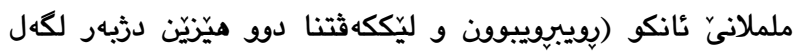

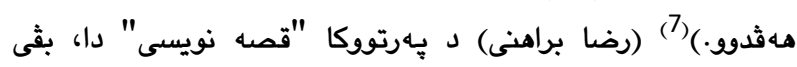

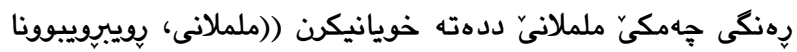

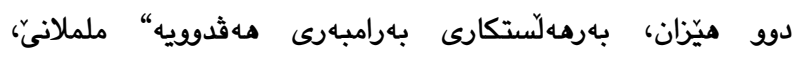

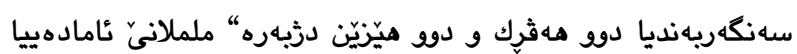

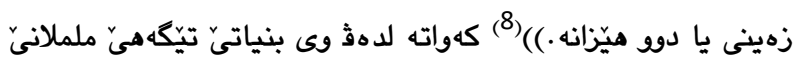
لسهر هـبوونا دوو هيَزيّن دزبهر و ههثرك هاتيه ئاثاكرن. د دراماييّدا

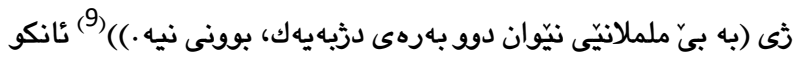

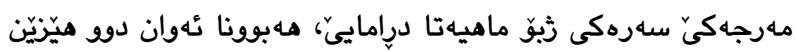
دزبهر و ههث ئاراستهيه " جونكى دراما هـردهم ((ههلكرى دواليزمى

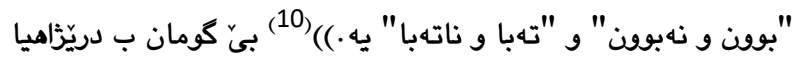

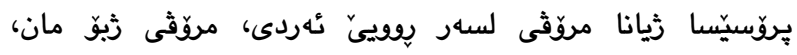

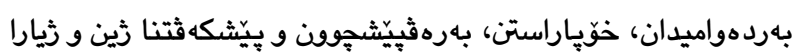

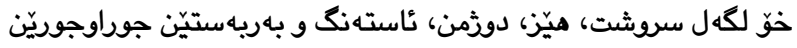
ئهثى جيهانىّ، د ململانهيهكا توند و دثوار دا بوويه تاكو شيايه

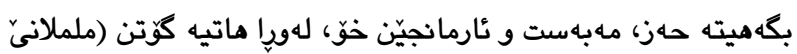

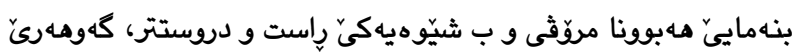

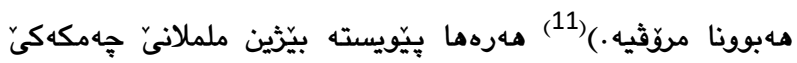

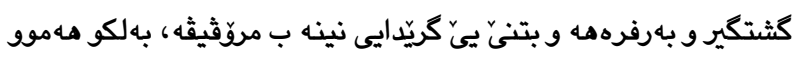

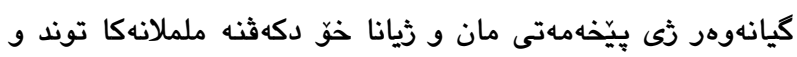

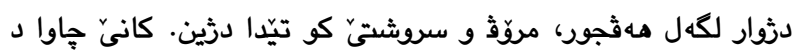

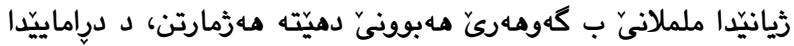

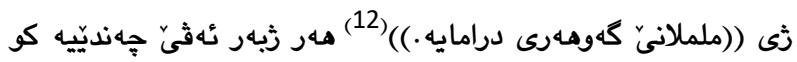

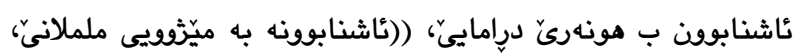

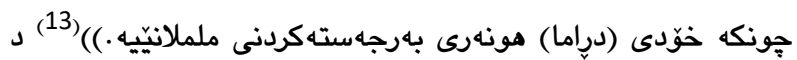
ناثا هـر دهقهكَّ دراماييدا، ئهكهر ململانى نهبيت، كاني جاوا ثيانا

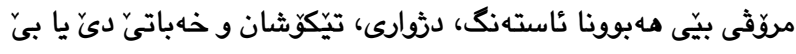

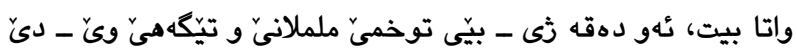

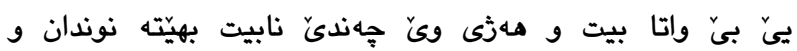


مهرهما مه ليّره باسكرنا يِّل و كرنكيا توخمى ململانا دراماتيكى

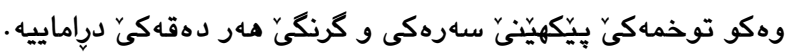

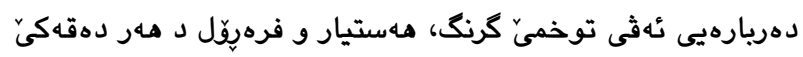

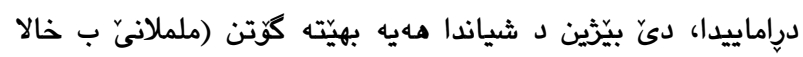

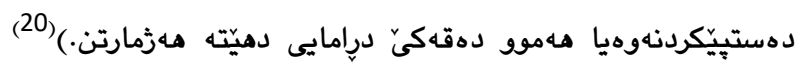

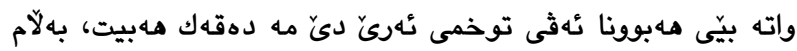

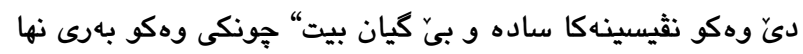

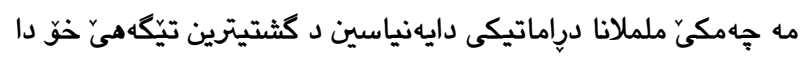

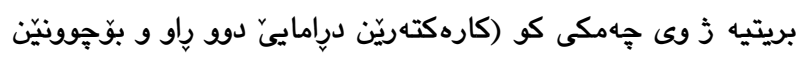

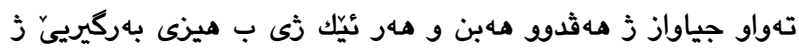

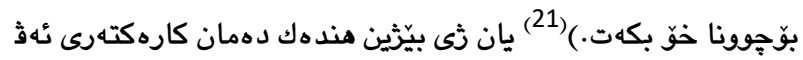

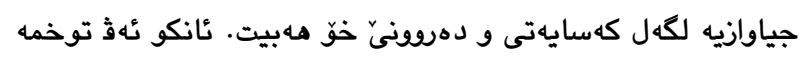

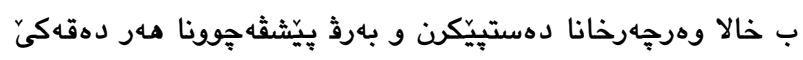

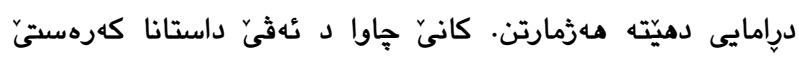
ثهكولينا مه، دهستيّيكرنا داستانيّ ب وهسفدايين و دانهنياسينا

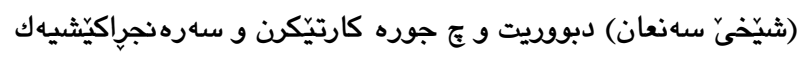

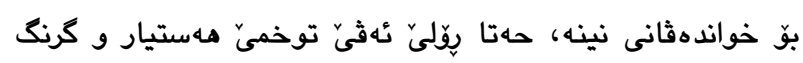

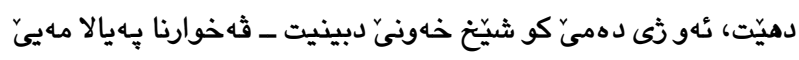

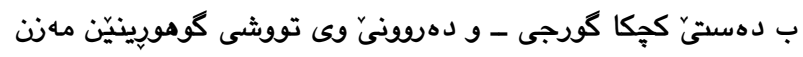

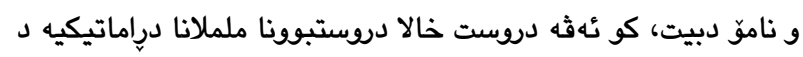

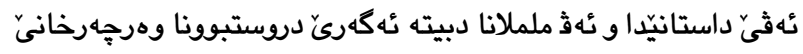

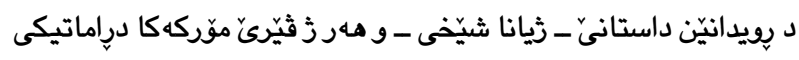
بقى دهقيقه خويا دبيت:

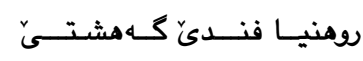

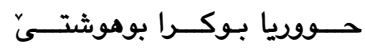

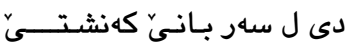

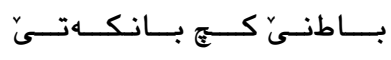

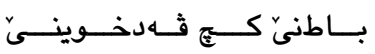

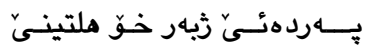

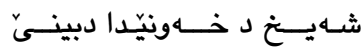

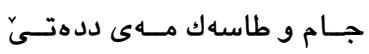

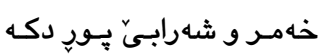

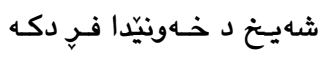

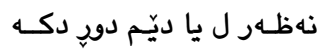

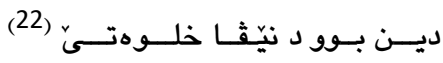

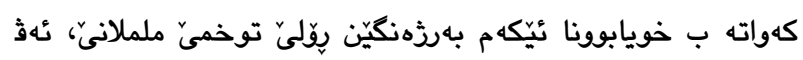

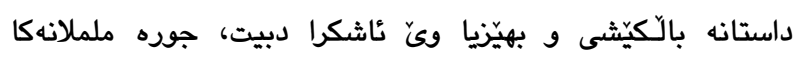

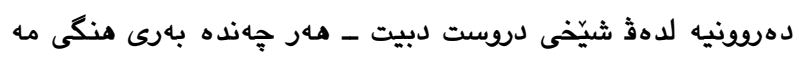

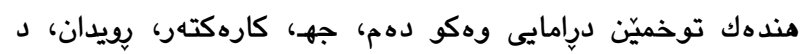

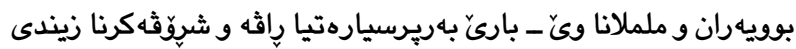

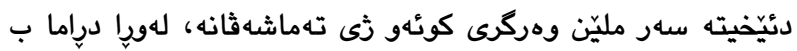

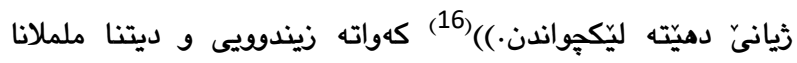

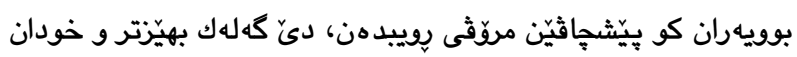

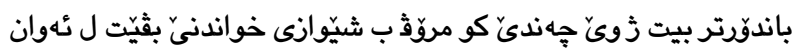
توخم و ته كنيكان بكه هيت. دهربارهيى يِيّاسهيا ململانا دراماتيك ديّ بيّزين (كروّكى ئهو

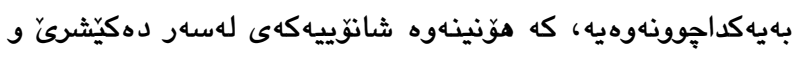

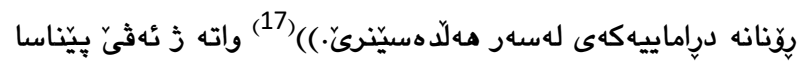

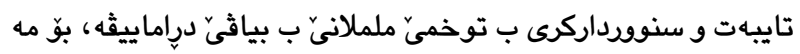

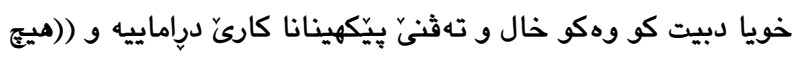
شانوكَريهك بيّى ململانى بوونى نيه، ململانيّ وا دهكات دهقى وهى

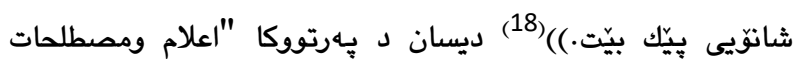

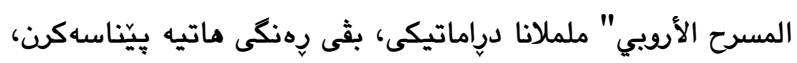

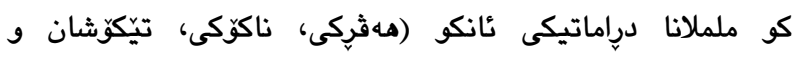

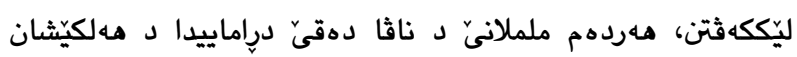

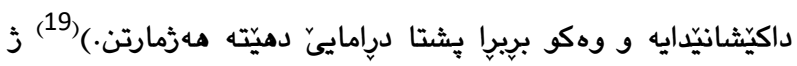

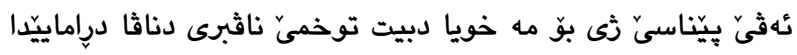

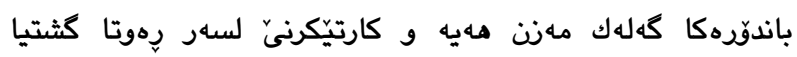
يروّسيّسا درامايى دكهت و وهكو خالا كوّمثهكهرا ههموو توخم و تهكنيكيّن دراماييه. ب بوّجوونا مه حهتا ئه في رادهيى بو بوهنقه كرن

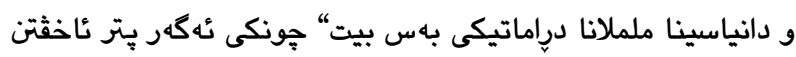

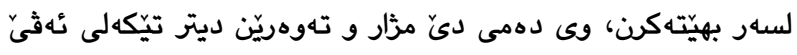
خالىّ بن، كو نئه ثَى يِّل و كرنكيا ئه ثى توخمينه . 2.4. رِّل و كرنگيا ململانا دراماتيكى: دهربارهيى يِّل و كرنكيا ململانا دراماتيكى، سهرهتاييّ دىّ بيّزّين كو د ئهدهبياتيّدا ب كشتى و د دراماييّدا ب تايبهتى، هـر توخم و ونه تهكنيكهكي يِّل، تايبهتمهندى و كرنكيا خوّ مهيه" ب تايبهتى ثى ئهكهر ئه م به حس ل تهكنيك و توخميّن دراماييّ بكهين، مهموو وهكو

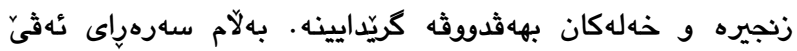
هـهيوهندى و خهباتا كولكتيثيا ئهثان توخم و تهكنيكان ثى، هندهك

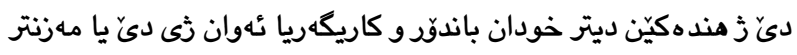

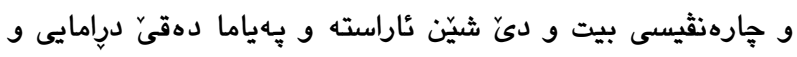
نواندنا وى بهرهث ئاراستهيين جياواز و جوراوجورثه ببهن و بينه

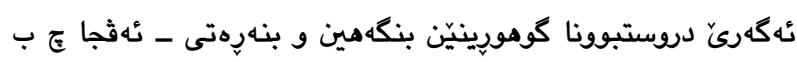

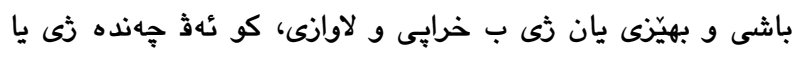

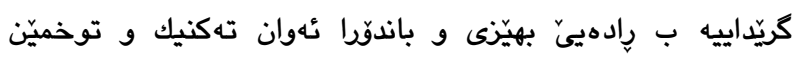

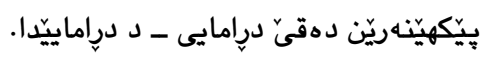




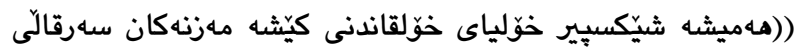

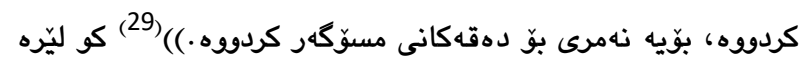

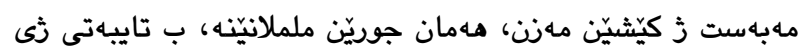

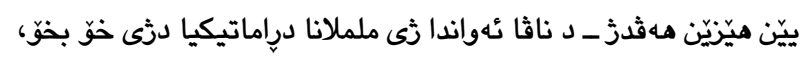

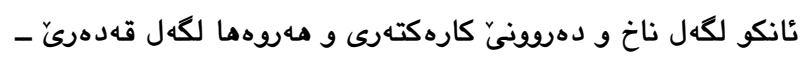

$$
\text { دناثا دهقيْن ئهوان ييّن دراماييدا. }
$$

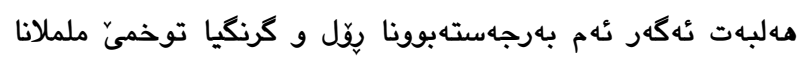

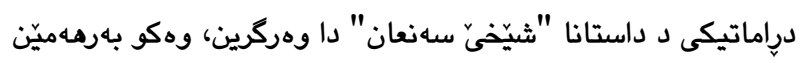

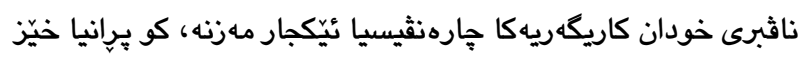

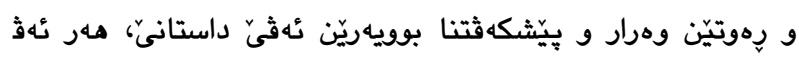

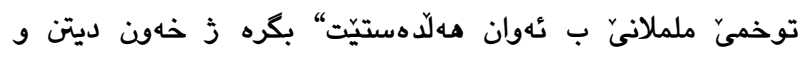

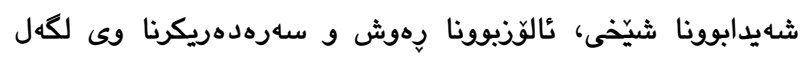

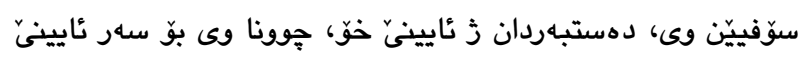

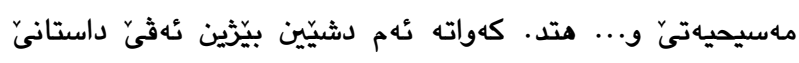

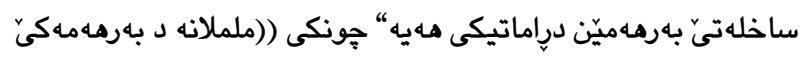

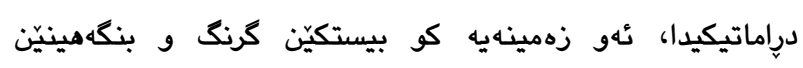
يويدانهكي بهاثدووثه كريّددهت. هوّكارىّ ههبوونا ئهوان بيستكان و

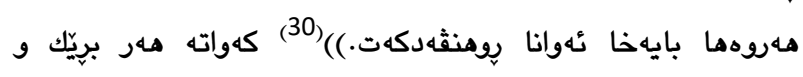

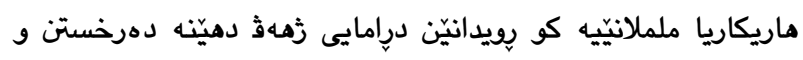

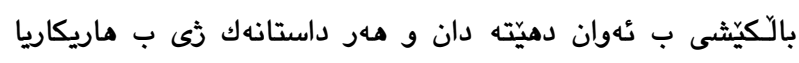

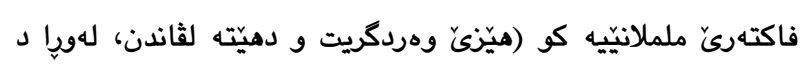

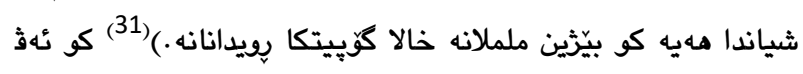

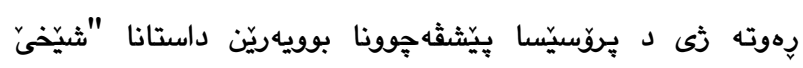
سهنعان" دا بهرجهسته دبيت.

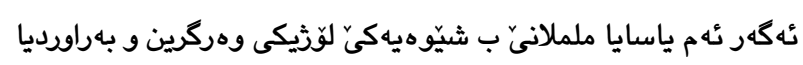

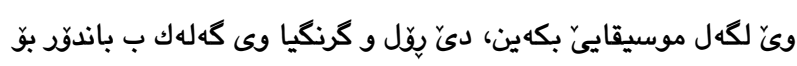

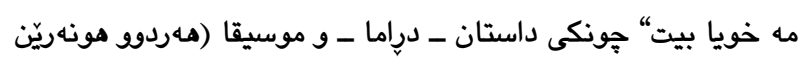

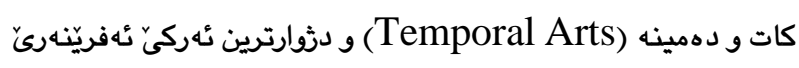

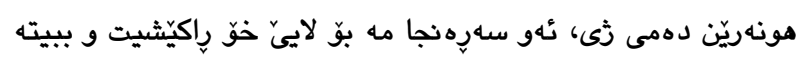

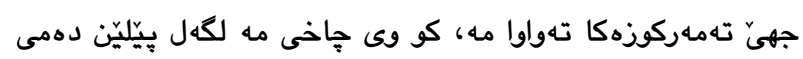

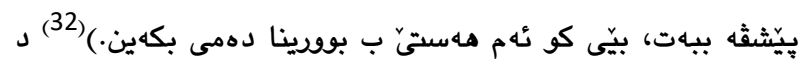

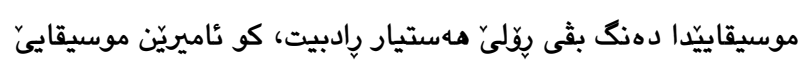

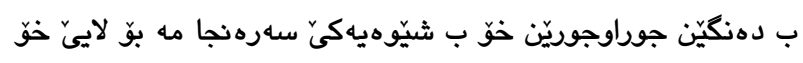

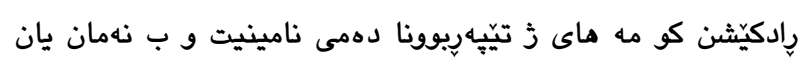

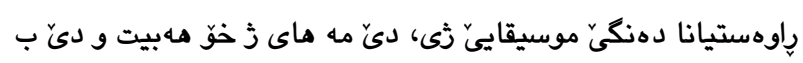

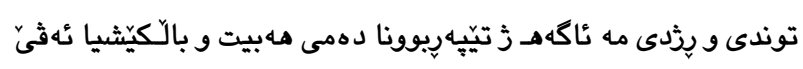

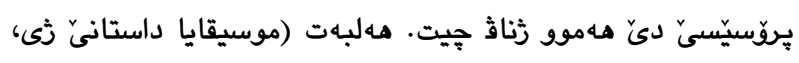
توخميَ ململانيّيه، حهتا وى دهميَ كو مزد و سوّزيّن مه كريّدايى و

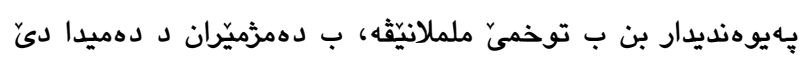

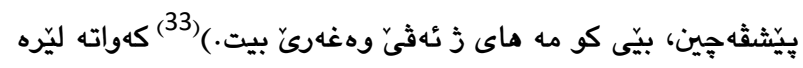

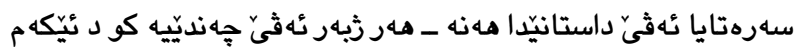

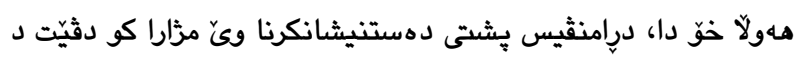

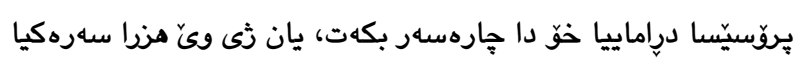

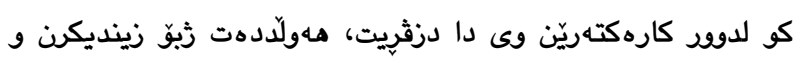

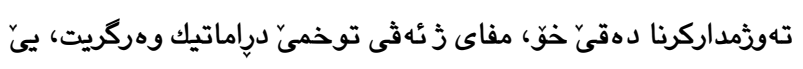

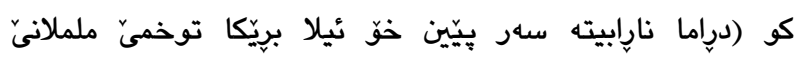

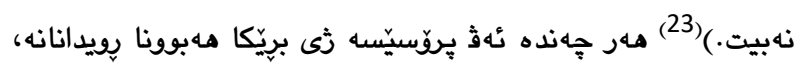

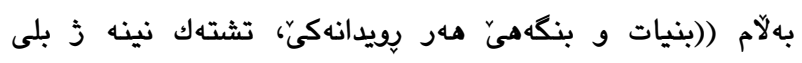

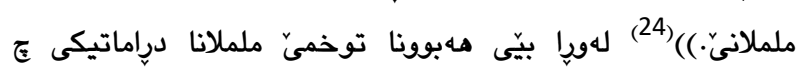

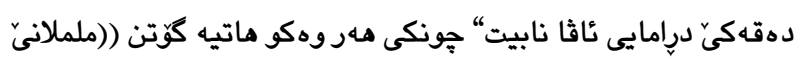

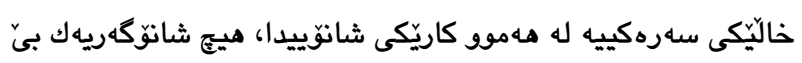

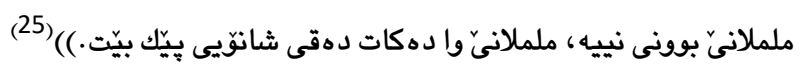

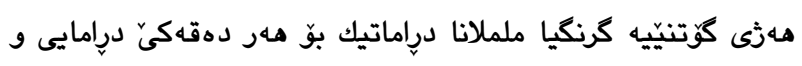

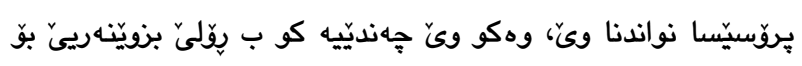

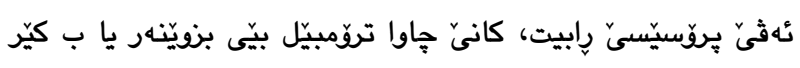

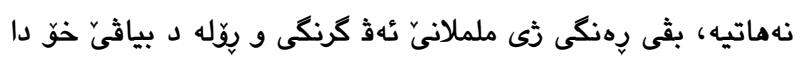

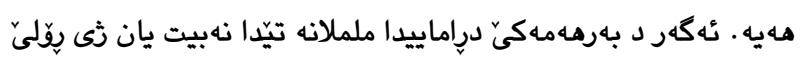

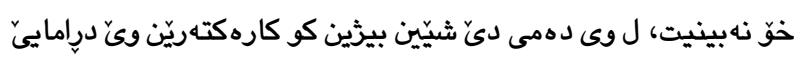

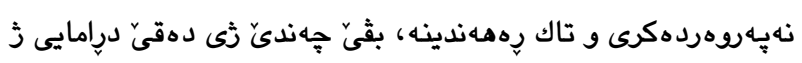

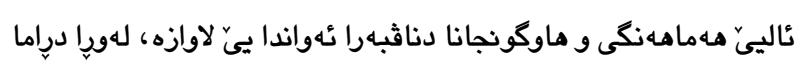
وى دهمى دىّ تووشى كهثتن و راوهستانيّ بيت" جونكى عَ هيزهاكا

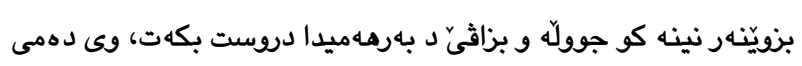

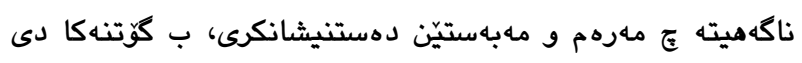

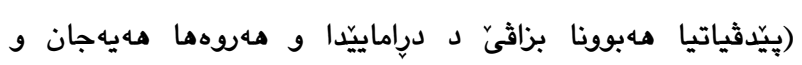

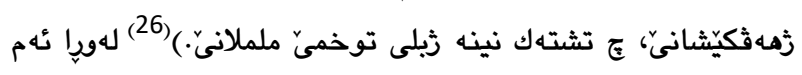

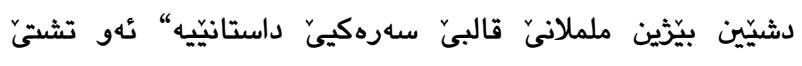

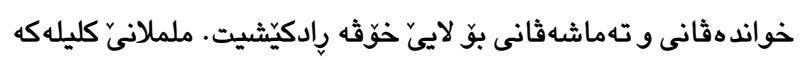

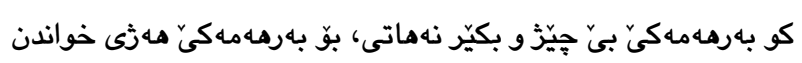
و ته ماشهكرنى دكوهوريت. دكارين كرنكيا توخمى ململانيّ ز لايهكيّ ديترثه ذى بدهينه خوياكرن،

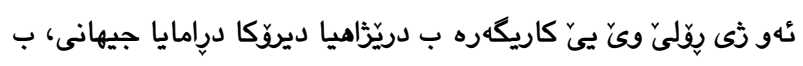

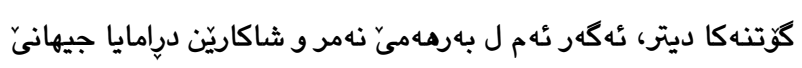
بنيّرِين، ديّ بينين كو هوَكاريَّ زيندويى و بهردهوام جهي ثهكولين و

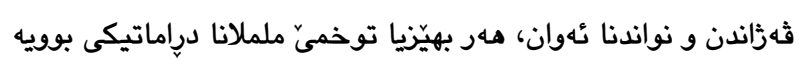

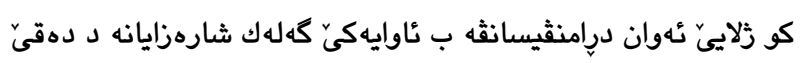

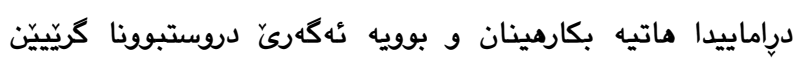

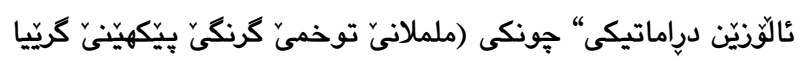

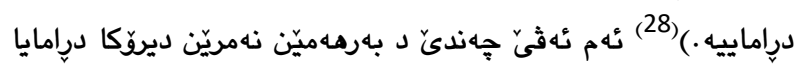

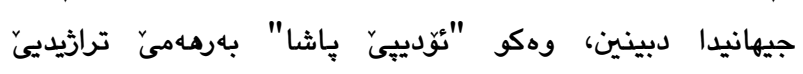

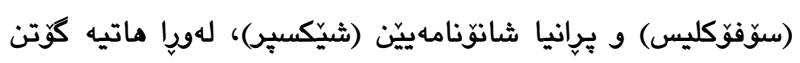


بهرجهسته دبن. هوّكارهكيّ دى ثَى هوَكارهكيّ دهرهكيه، كو كريّداييه

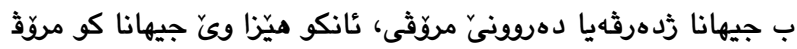
تيّدا دريت. كهواته ب ليّكدان و تيّكهلكرنا ئهثان مهردوق جوريّن

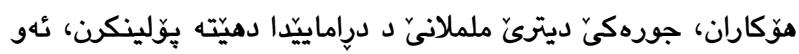

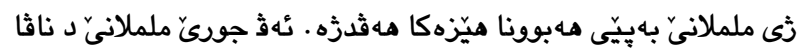

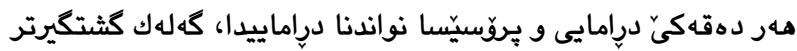

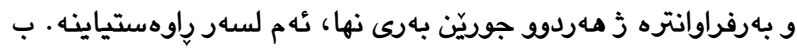

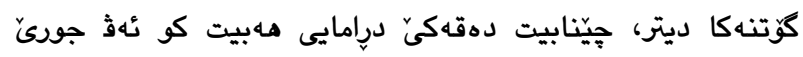

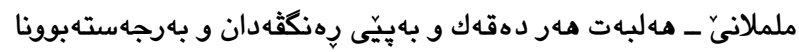

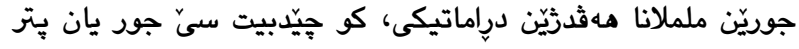

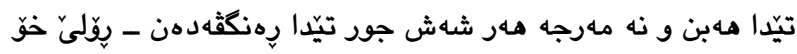
تيّدا نهكيّرِيت. ئهث جوره ثى لسهر شهاش جوريّن سهرهكى دابهش

دبيت:

1. مروّث دثى خوّ (Man against himself)

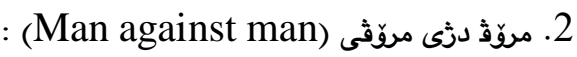
2.1 ململانا كوَتنى (Verbal conflict) 2.2. ململانا جهستهيى (Physical conflict) 3. مروّث دثى دثى جثاكى (Man against society)

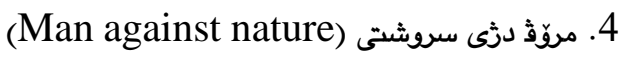
5. جثاك درى جثاكى (society against Society) 6. مروّث دثى جارهنثيسى/قهدهريّ (Man against fate)

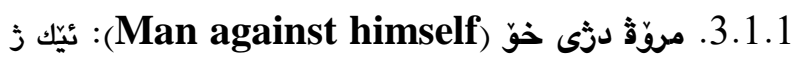
تايبهتمهندييّن كو هـر مروّثهكي ههنه، ئهوه كو دكاريت هـر دهميّ

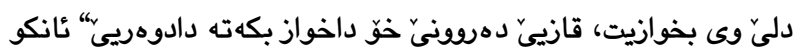

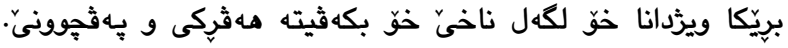

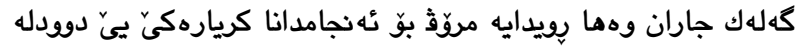

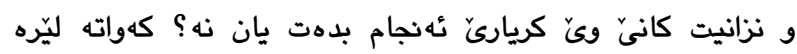

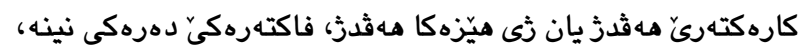

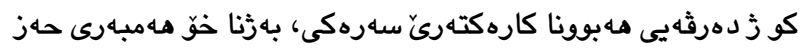
و ويستين وى رإكهت و ببيته ئاستهنگ د ريّكا كه هشتنا ب نارمانجا

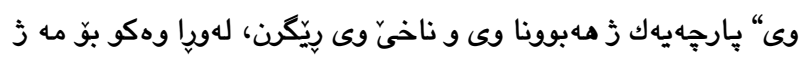

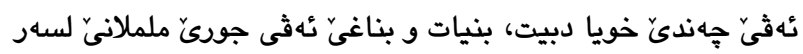

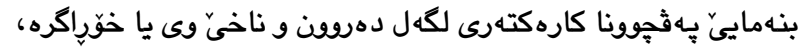
كو شيانيّن درامنثيسى د بهرجهستهكرنا مهلّكاثتنا دهروبنيدا،

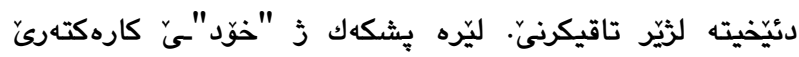

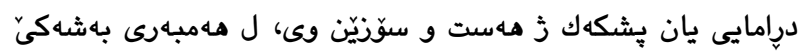

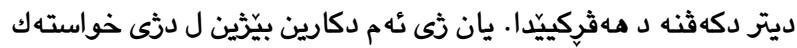
و ئيرادهيا بهرجاثا وى ياخى دبيت و مهبوون و ناخيّ وى دئيخيته بهر

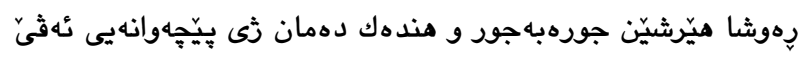

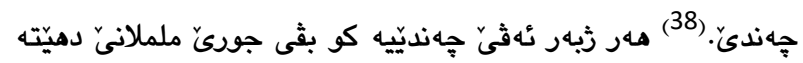

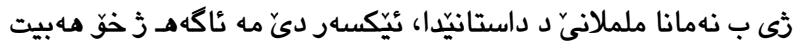
و ئهو راكيّشان و بالكيّشيه نامينيت. كهواته كانيّ جاوا موسيقا مروّثى

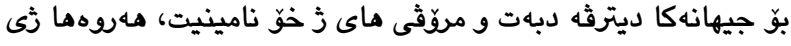
توخمى ململانيّ د داستان و درامايِّدا ب وى يِّلى رادبيت، لهوريا

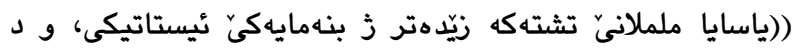

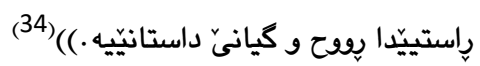

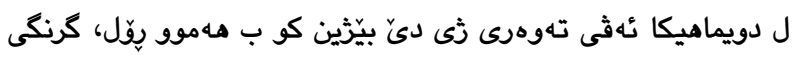

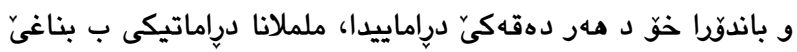

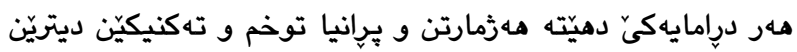
درامايى ييّن وهكو ديالوّگ، يويدان، كارهكتهر و حهتا ديمهنيّن درامايى

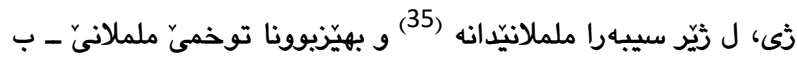

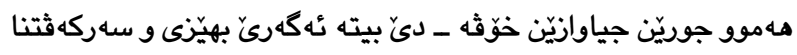

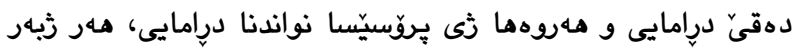
ئهثيَ جِهنديِيه ماتيه كُوتن ((ململانيّ وهكو قهرهقووديه د بِيّكهاتا

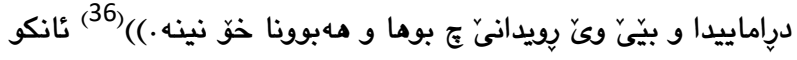

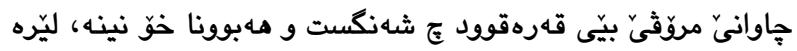
ململانيّ ثى وهكو وى قهرهقووديه بوّ دهق و بِروّسيّسا نواندنان

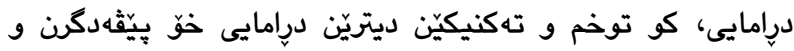
بهردهواميى ددهنه مهبوونا خَّ.

\section{3. جوريّن ململانا دراماتيكى}

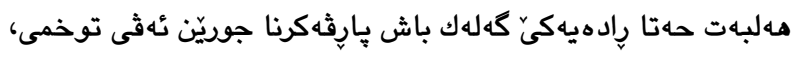

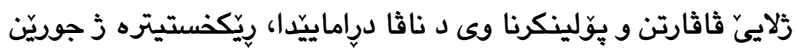
ديتريّن ئهدهبى. لدويث ئهوان ليَكَهِيانا مه بو دهستنيشانكرنا جوريّن

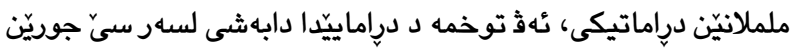
سهرهكى دبيت. كو بثى رهنكيّ ل خواريّنه :

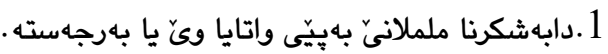

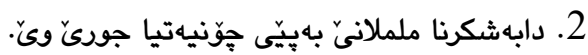

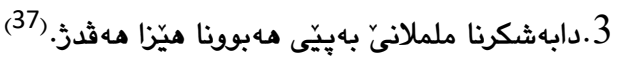

3.1. دابهشبوونا ململانا دراماتيكى لدويث هلبوونا هيّزا

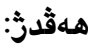
هـر وهكو بهرى نها مه ئامازْهِيْكرى، كورتترين دانهنياسينا توخمى

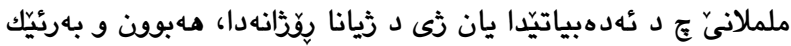

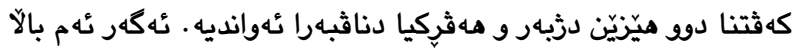

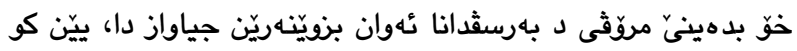
وى ناجار ب لثين و هه ثركيى دكهن، كارثهدانيّن جوراوجور ههنه.

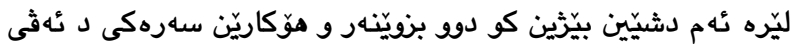

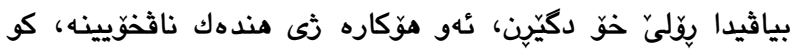

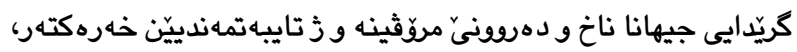
كهسايهتى، رهوشت، سهرهدهريكرن، ناخ و دهرونيّ مرّڤى 


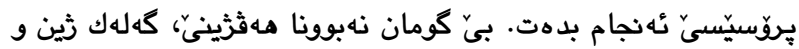

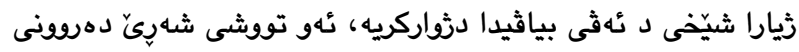

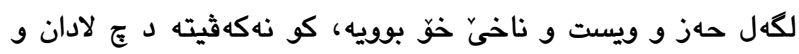

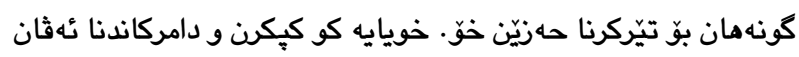

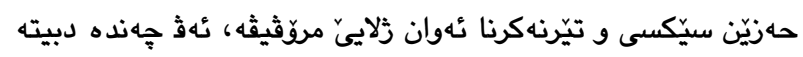

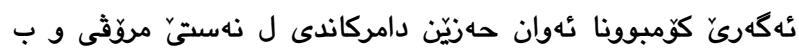

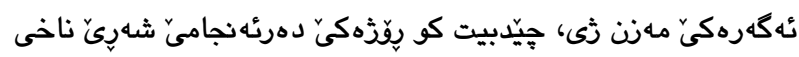

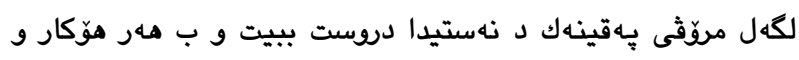

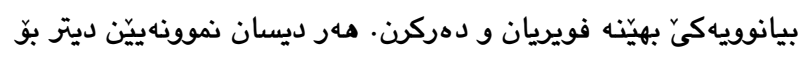

$$
\text { كُهى بياثى: }
$$

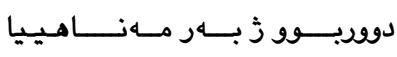

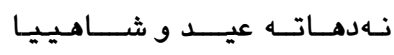

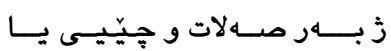

(40)

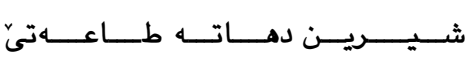

دهفـتــــرا صـــاحب جـهـــالان

ثــــرح و مهتنى نولف و خــــالان

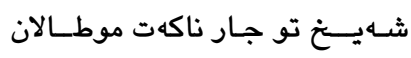
(41)

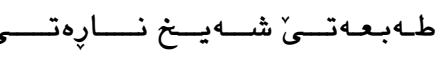

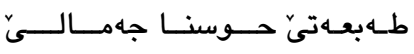

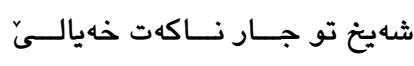

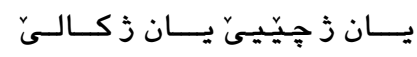

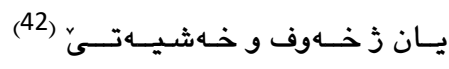

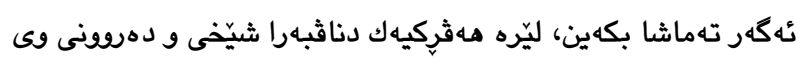

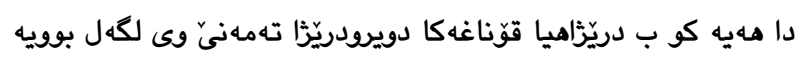

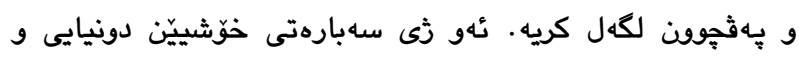

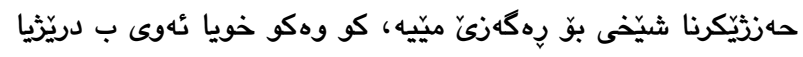

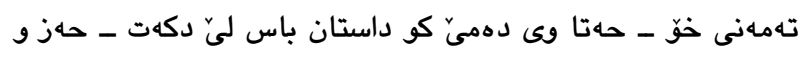

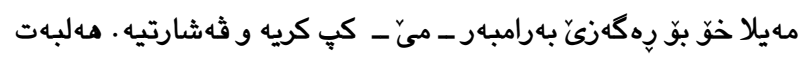

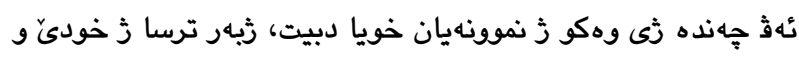

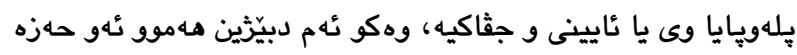

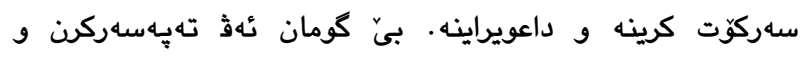

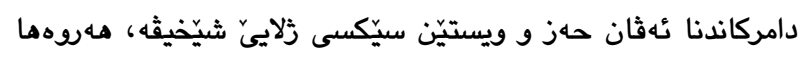
درايه تيكرنا ئهثان خواستهكان مهر وهكو بهرى نها مه نامازٔهِيّداى، زيهر هوَكاريّن جورهبهجوريّن وهكو نايينى، كوّمهلآيهتى، رهوشتى

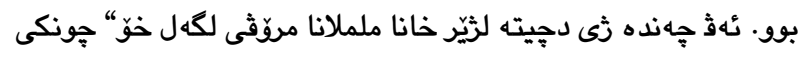

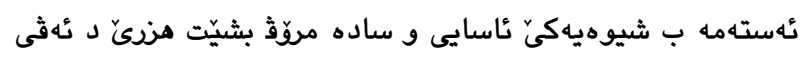
بياثيدا نهكهت و خودىّ مروّث ب حهز و ويست و شههوهت ئافرانديه، لهورا تيرِركرنا ئهوان حهزان ب دريّرَاهيا تهمهنى، گهلهك كارهكي

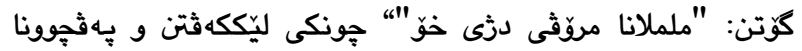

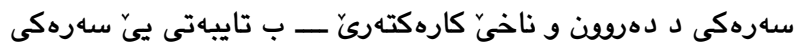

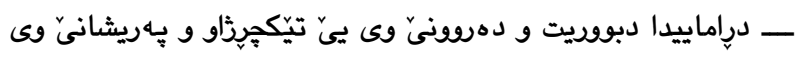
دكهته زهمينهيها لهبار و كونجايى ثبو هـر جوره كوهورينهيّ.

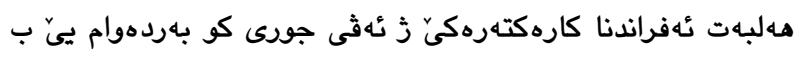

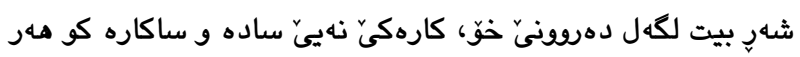

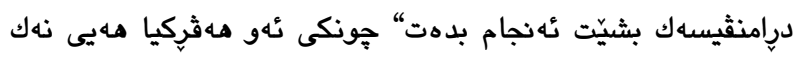

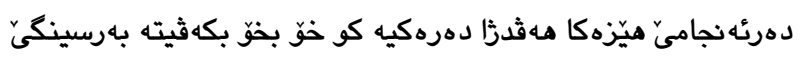

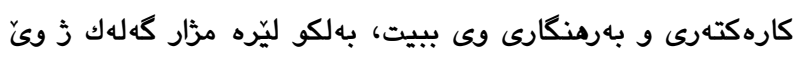

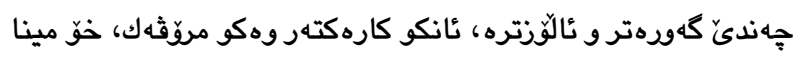

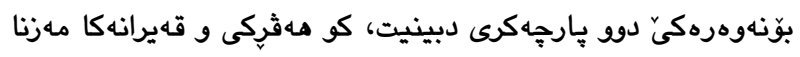

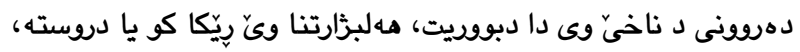

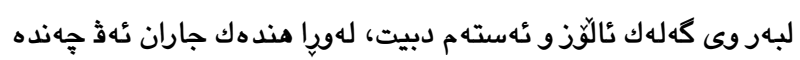
- ئهكهر نهشيا مهثسهنگى و كونجانهكي دناثبهرا ئهثان مهردور

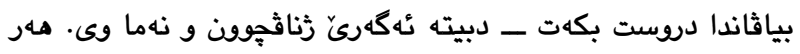

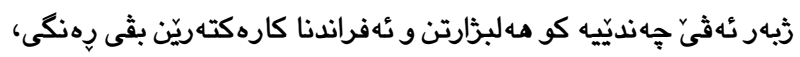

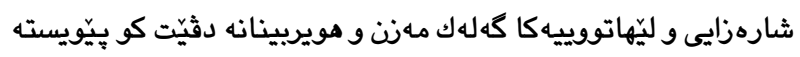
درامنثيس بهرجاث وهريكريت و رِهجاو بكهت.

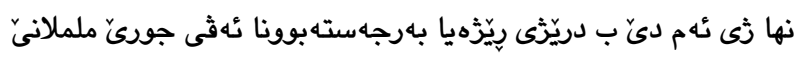

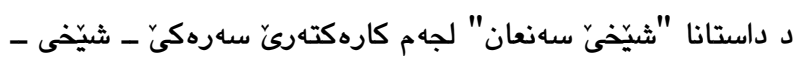

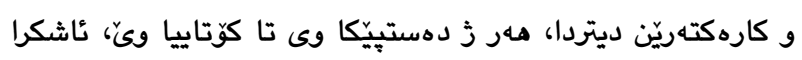

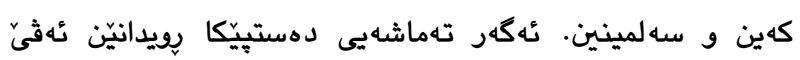

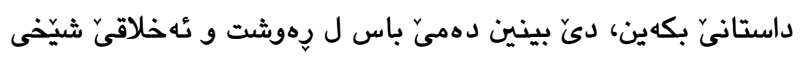

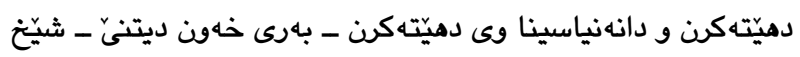

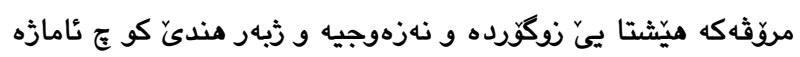

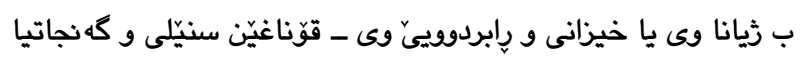

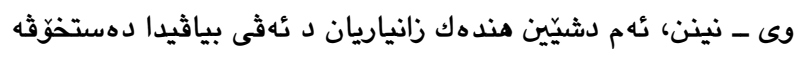

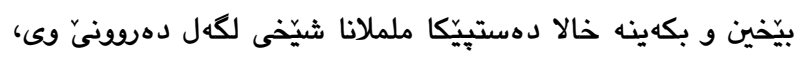
(فه قيى تهيران) دبيّزيّيت:

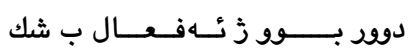

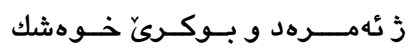

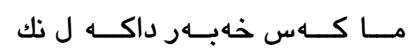

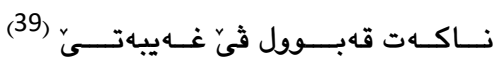

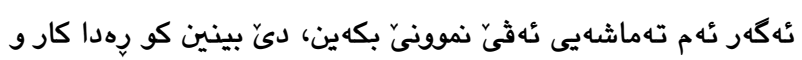

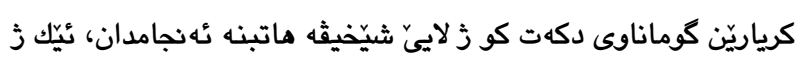
ئهوان كرياران ثى خوّشى و تيّركرنا حهزيّن سيّكسيه لكهل كوريّن

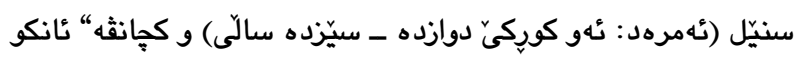

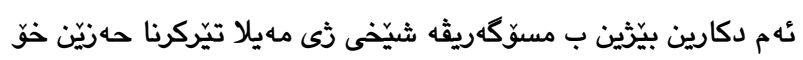

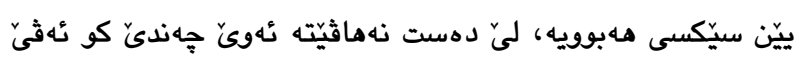




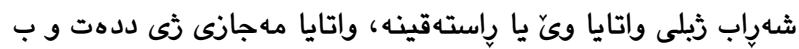

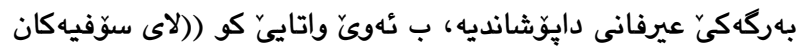

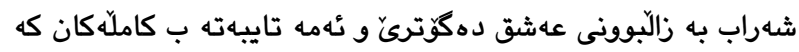

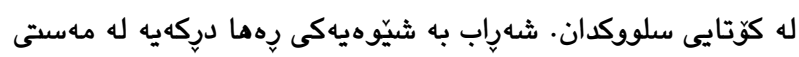
خّوشهويستى و جهزبهى حهق، عهشق و زهوق و مهستييان به شهراب

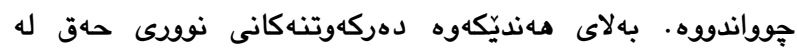

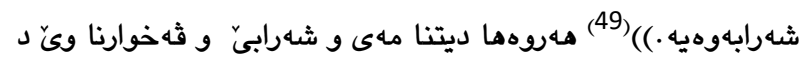

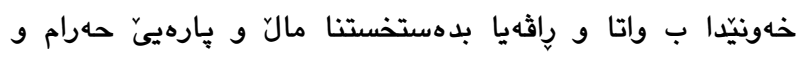

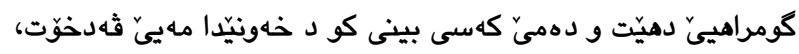

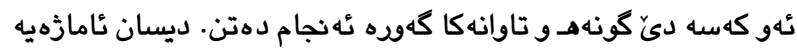

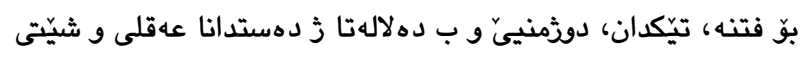

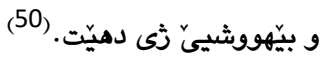

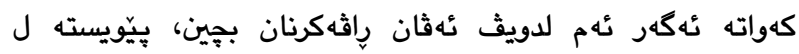

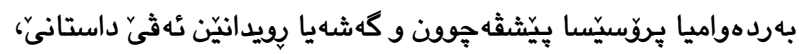

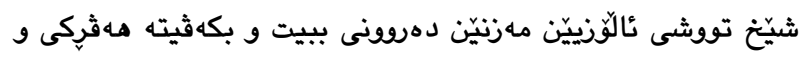

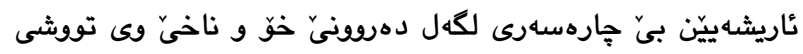

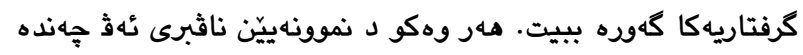

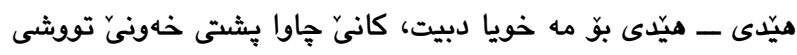
هه ثركيهكا مهزنا دهرونى دبيت و دناقا خهلوهتيّدا كُّشه كير دبيت.

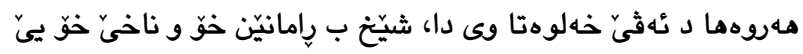
يِيّلدار، تووشى ململانهيهكا مهزنا بحّ ويّنه دبيت، كو ع جاران ئهو نهكهتيه د رهوش و بارودوخهكيّ وى رِهنيدا:

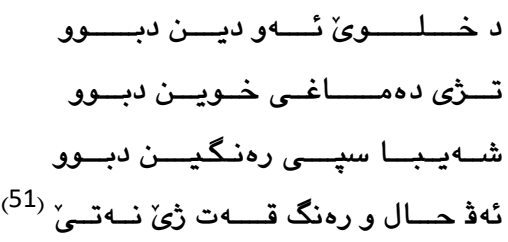

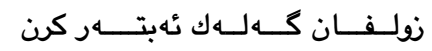
جسهر و مـنـاث كـهر كـهر كرن

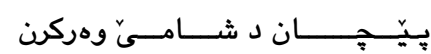
(52) (2)

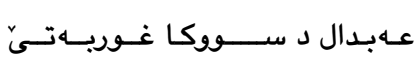

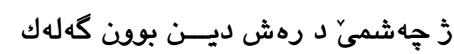

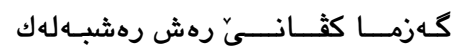

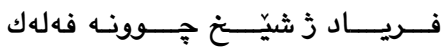

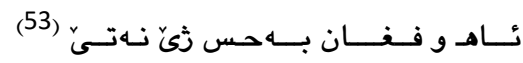
كهواته شهاريّ دناقبهرا دل و ميّشكيّ شيّخى دهربارهيى خهونا وى و

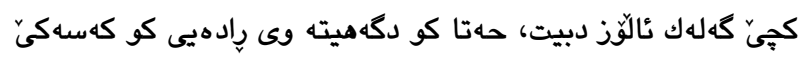

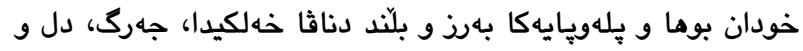
دهرونيَ وى بسوّثيت و ئاهـ و فيغانيّن وى بجنه وناسمانان و هيّزا

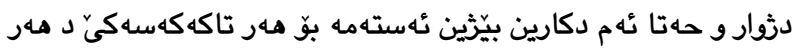
بياث و پِله و يِوّسته كيّدا" جِونكى (حهز و مهيلا سيّكسى ذ ويستيّن

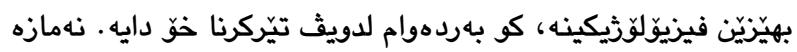

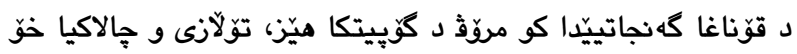

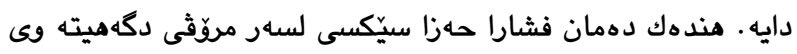

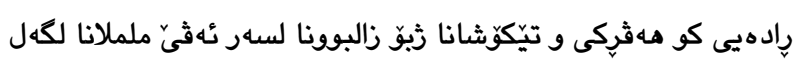

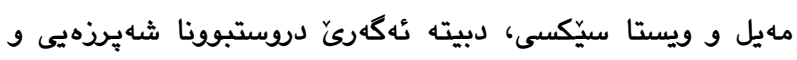

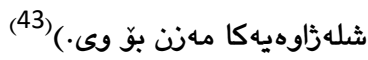

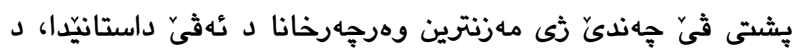

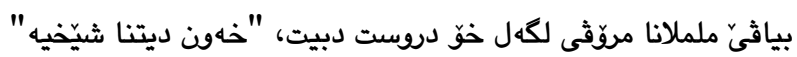

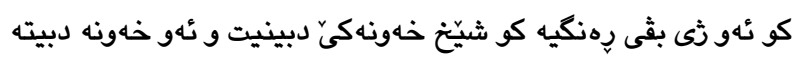

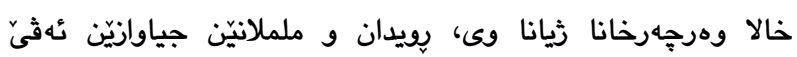

$$
\begin{aligned}
& \text { داستانىّ: }
\end{aligned}
$$

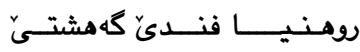

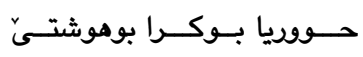

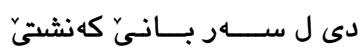

$$
\begin{aligned}
& \text { (44) }
\end{aligned}
$$

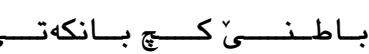

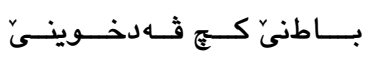

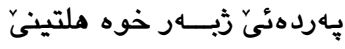

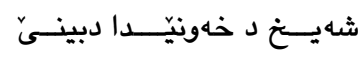

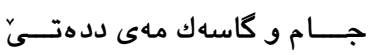

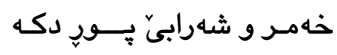

$$
\begin{aligned}
& \text { شهيتخ د خهونيّدا فــــر دكـه } \\
& \text { نهظــر ل يــا ديّــم دورِ دكه }
\end{aligned}
$$

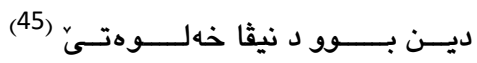

يا فهره بهرى كو ئهم ليّره بهحسى كاريكهريا ئهثى خهونيّ لسهر

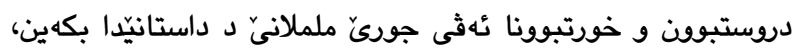

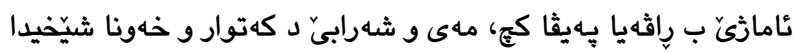
بكهين، كانيّ تَ واتا ددهت. د (خهونامهى كوردى) دا دها دهريارهيى ديتنا كجِكيّ د خهونيّدا و رااثهيا وىّ دبيَّيت: كَّ (له خهودا قوورسى و

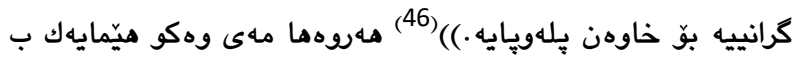

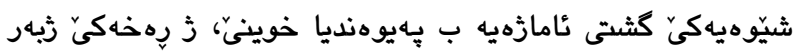

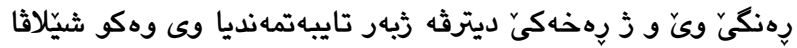

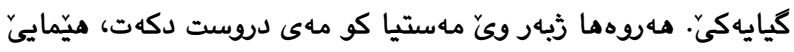

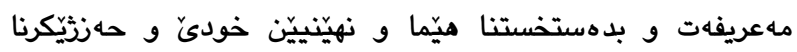

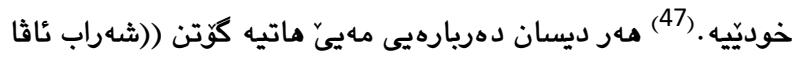
زيانيّه، راستييه، راستى يا د شهرابيّدا. هيّزا غهريزه و حهزا

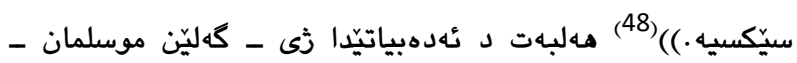




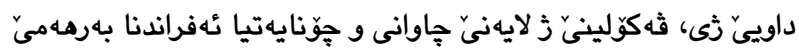

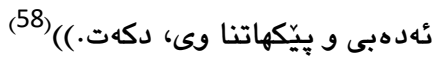

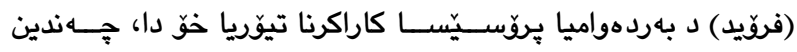

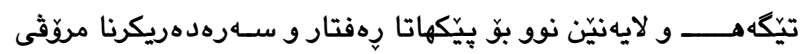

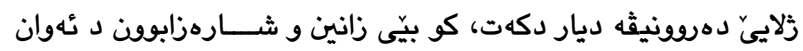

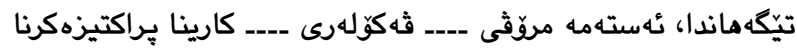

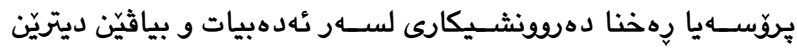

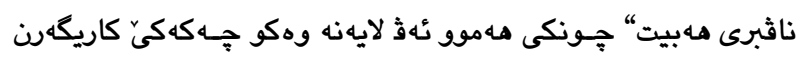

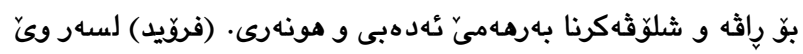

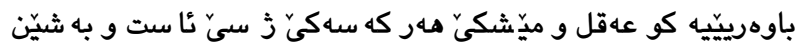

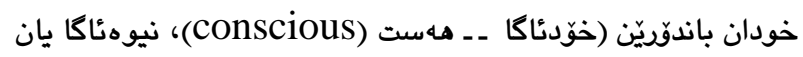

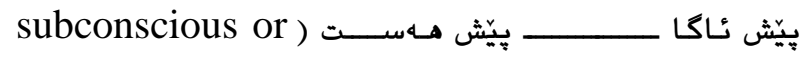

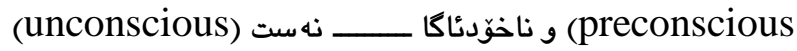
بِيَكدميَت.)(59)

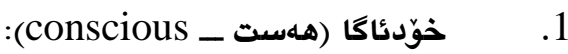
مهبهست ز نَهثى بهشى ((باريّكى به ئاخابوفن و مهستكردنى ديارده

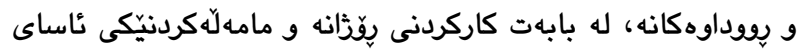
له كهل خوّد و دهورويهرهكهى هوّشمهندانهيه كه بريتييه له ناوجهـى

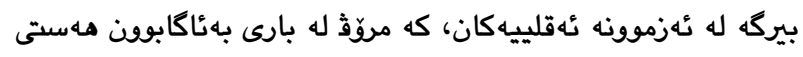

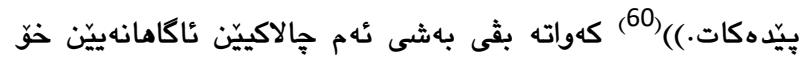
نئه نجام ددهين.

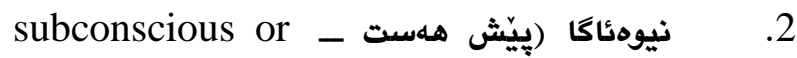
$:$ (preconscious ئهو به شهيه كو مروّث ب ساناهى دشيّت ئهوان تشتان بينيته بيرا خّو

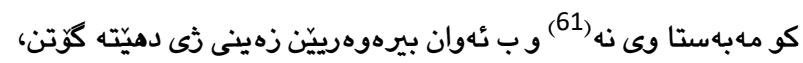

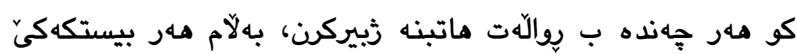

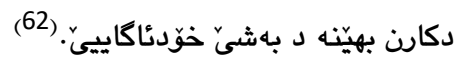
3.

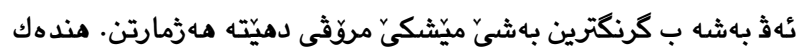
ز بيرهوهرى، ههزاندن و حهز و ويست، دهرثهي دهسهالاتا خوّدئاكاييا

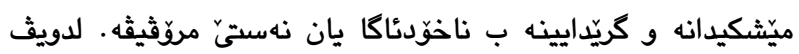

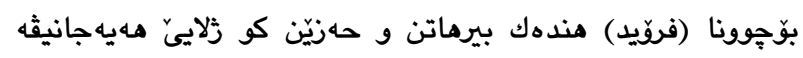

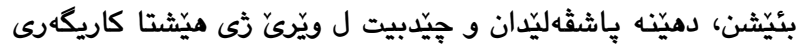

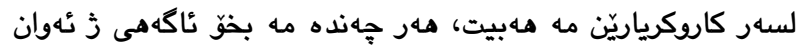

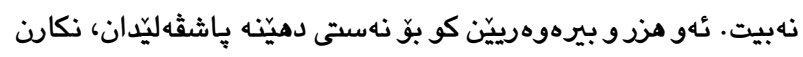

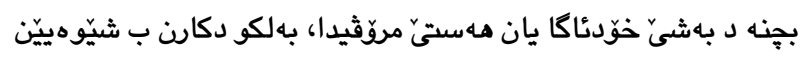
نهراستهوخٌ كو ز ريّكيّن خهونان، ناكار و سهرهوهريكرنيّن

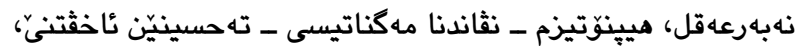

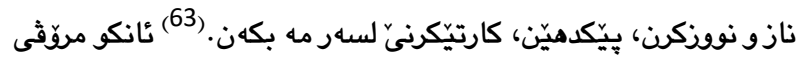

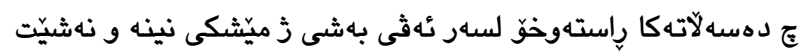

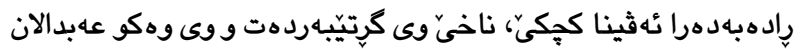

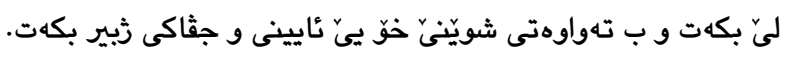

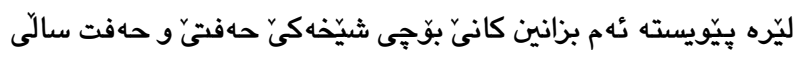

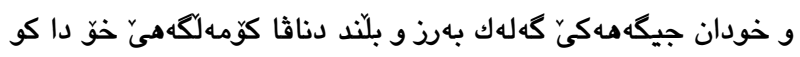

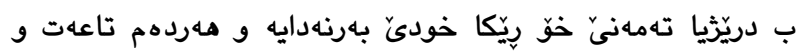
عيبادهتيّ خوداييّ مهزن كريه و خوّ ذَ ههر جوره خوّشى و حهز و

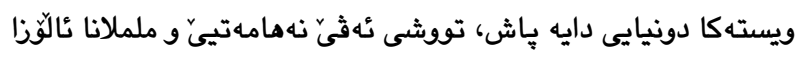

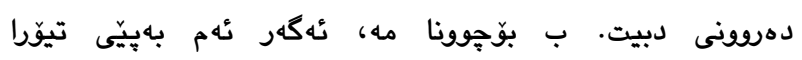

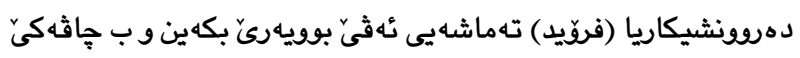
دهرونشيكاريانه مهلَّهانكاندنى بوّ بكهين، ديّ حهتا رِادهيهكي

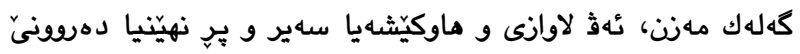
شيّخى بوّ مه ميّته يورهنقهكرن و سه لماندن.

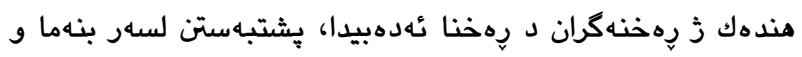

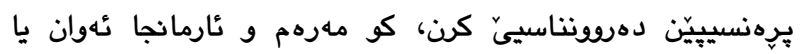
سهرهكى د ئهثى بياثيدا ئهو بوو (رهوتا ناخى و رهوشا دهرئ دهونيا

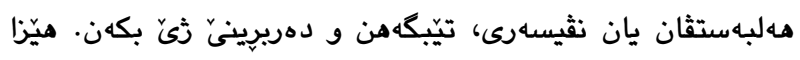

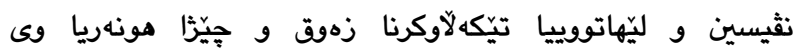

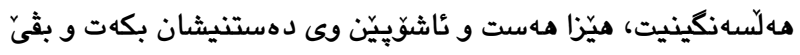

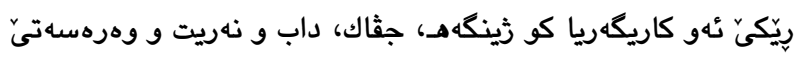

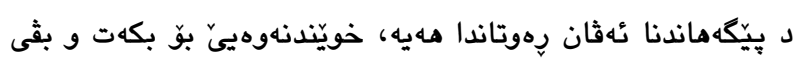

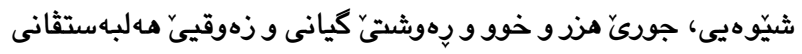

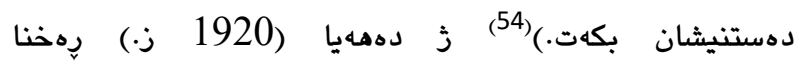

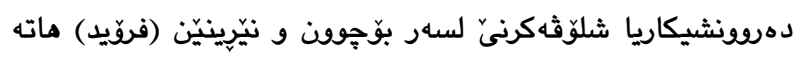

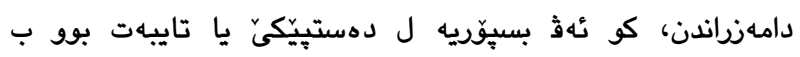

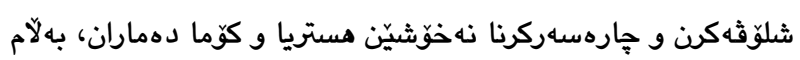

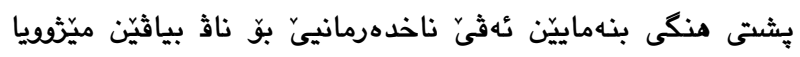

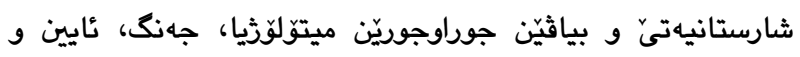

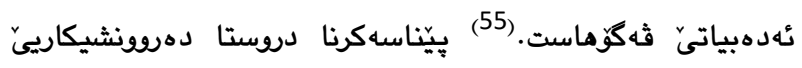

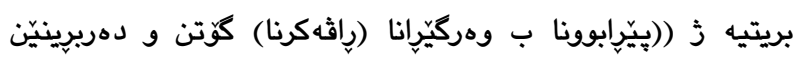

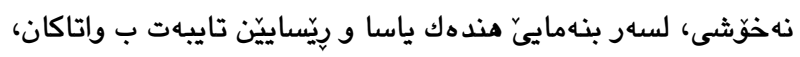

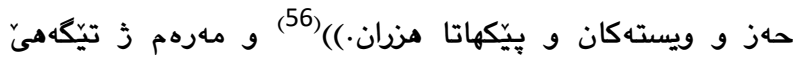

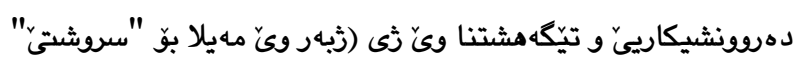

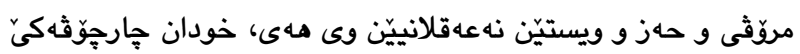

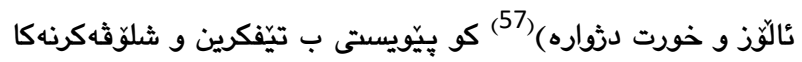
وردانه مهيه.

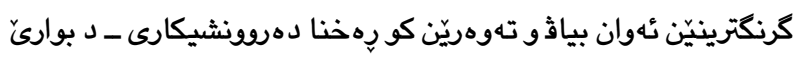
ئهدهبى و هونهريدا ـ داكوّكيّ لسهر دكهت، بريتينه ز (مثويلبوون

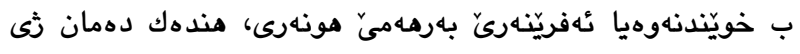

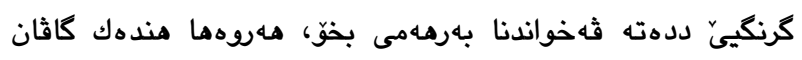

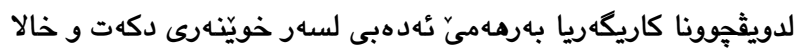


3.

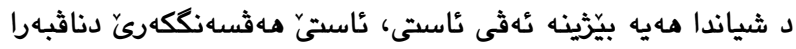

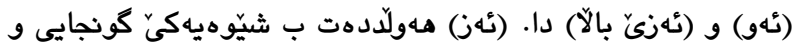
باش مهاثركى و ململانهيين دناقبهرا حهز و ويستيّن هـردهم برسييّن

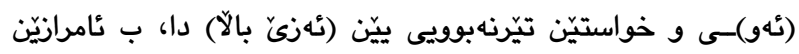

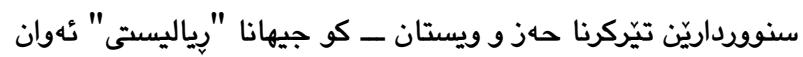

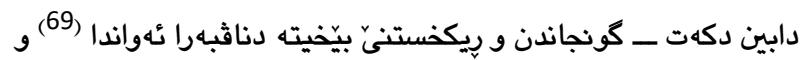

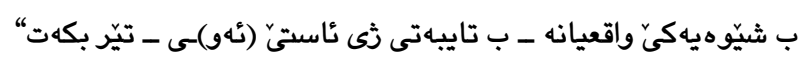
جونكى داخوازى و يِيّدثياتيِين (ئهو)سى، د جثاك و وزيانا ئاساييدا جهى رهزامهندى و هِهسهندكرنى نينن. ئانكو ئهم دكارين بيِرين ئاستى (ئهو)-سيّ كهسايهتيا مهر كارهكتهرهكي وهكو (دهريايهكيّيه كو لاييّن

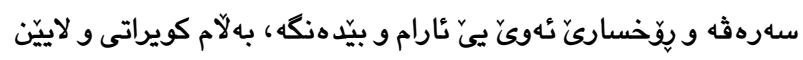

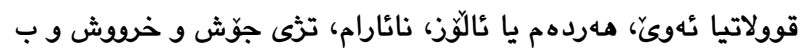

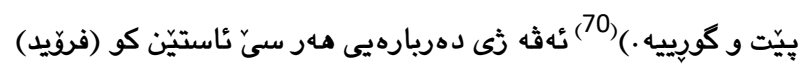
بو كهسايهتيا مروّىى دهستنيشان و دابهشكرينه. ليّره ئهم ديّ

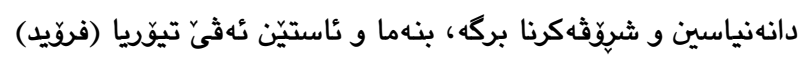

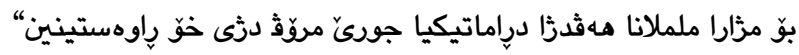

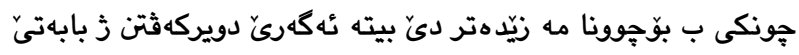
مثرارا مه يا سهردكى.

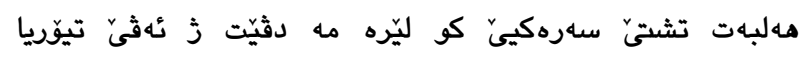
دهرونشيكاريا (فروّيد) د ئهثى تهوهريّ ثهكولينا خوّ دا مفاى ثَّ وهركرين، مزارا خهون و خهون ديتنييه كو (شيّخى سهنعان)

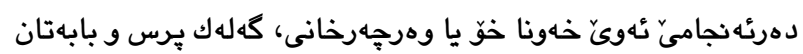

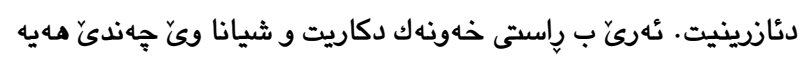

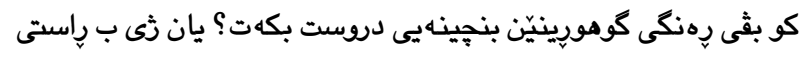
خهون ثهثن و دهربرا ئهوان حهز و ويستيّن مروّثيه كو ماتينه

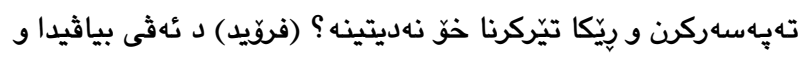

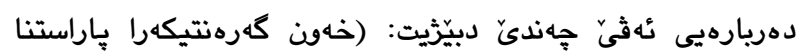
مهثسهنكيا دهرونيا مروّثيه، خهون بريتيه ز ثهزهن و خوياكهرا

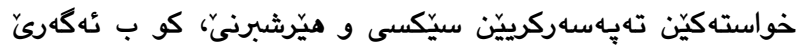

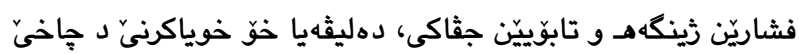

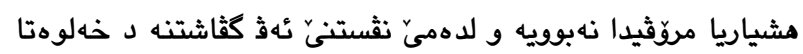

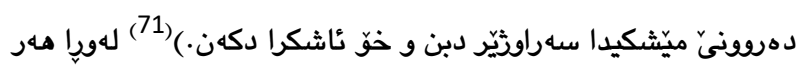

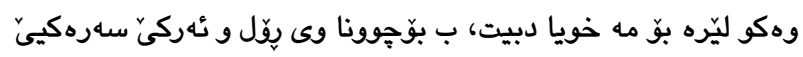

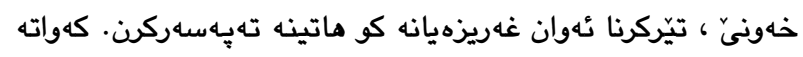

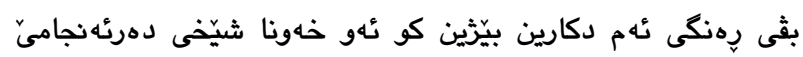
تهيهسهركرن و تيّرنهكرنا غهريزه و حهز و ويستيّن وى يِين

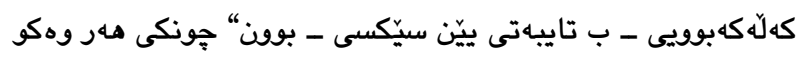

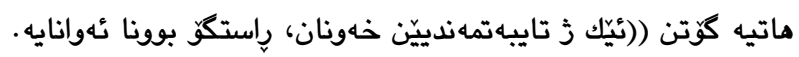

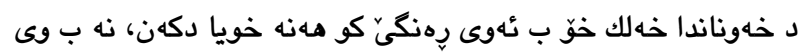

تج دهمهكي بقيّت، ئهوان مهموو بيرهوهرى و حهزان بينيته ئاستين هـ ست و بِيَش هـ ستيّدا.

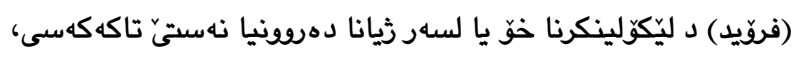

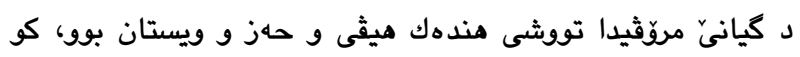

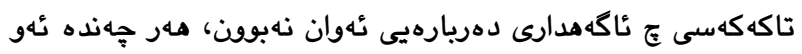

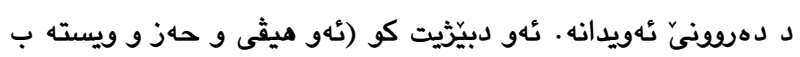

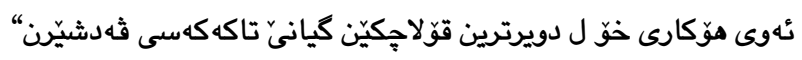
جونكى لكهل رهوشت، تيتاليّن جثاكى، داب و نهريتيَن نهتهوهيى

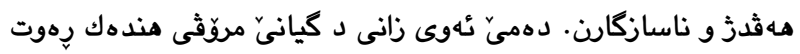

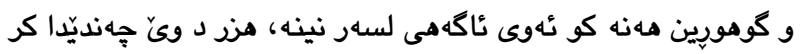
لوغز و تشتانوّكين خهونى كو بيّى هيج جاوانى و جِرايى، نئيرادهيا

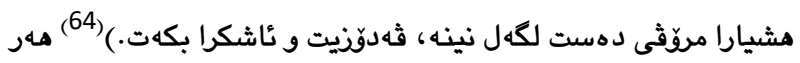

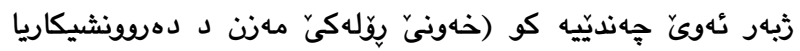

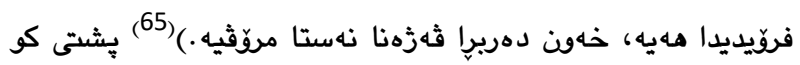

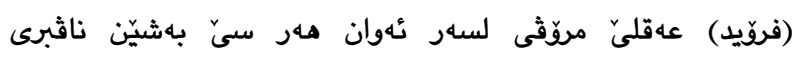

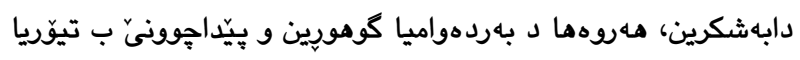

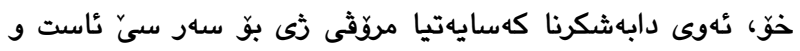

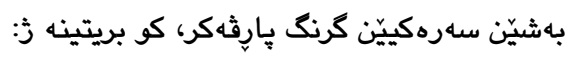
1

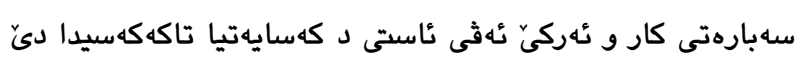

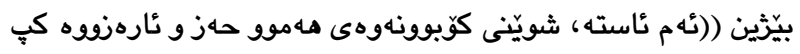

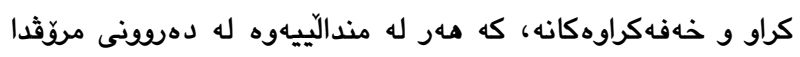

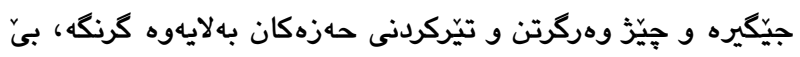

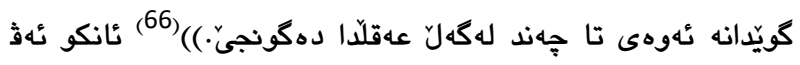

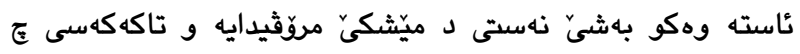

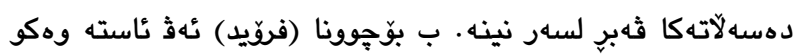

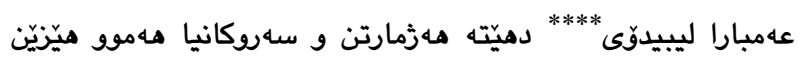

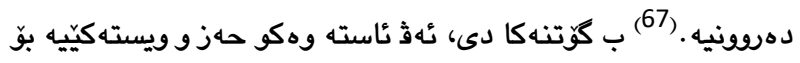

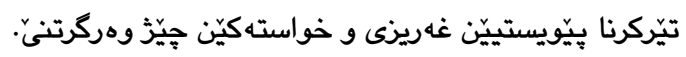

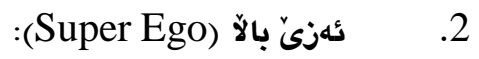

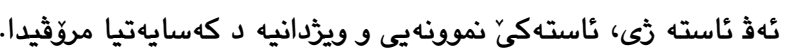

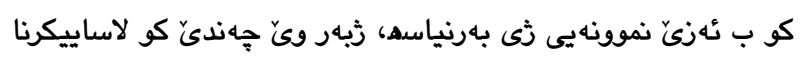

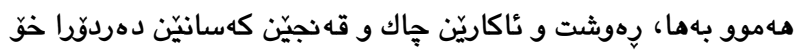

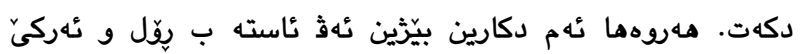

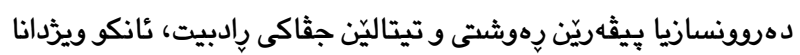

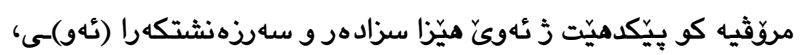
ئهكهر كار و كريارهك يان ثى ناشيرينى و نهزمهرياتيهكا دثى جثاك و و داب و بهريتينّ كوّمهلايهتى بكهت.

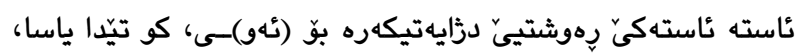
بنهما و تيتاليّن جثاكى تيّدا ده سهلاتدار و زالَن. 


$$
\begin{aligned}
& \text { مه ظهـــر دى يه صهبـــر ثىّ نهتيّ (76) }
\end{aligned}
$$

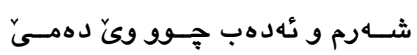

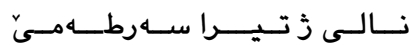

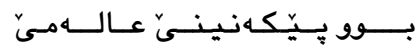

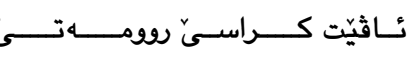$$
\text { (77) }
$$

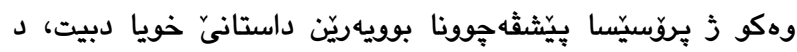

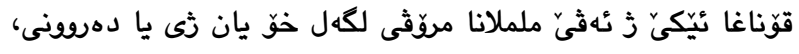

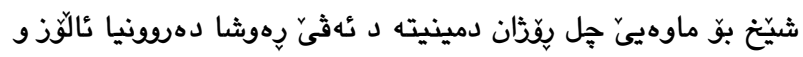

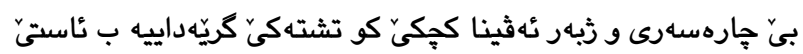

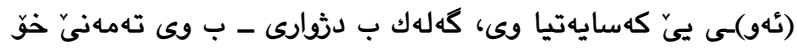

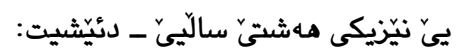

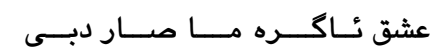

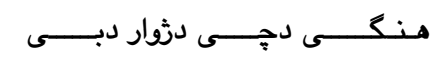

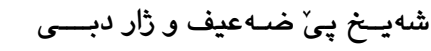

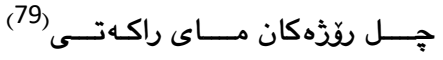

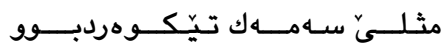

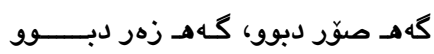

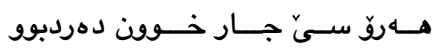

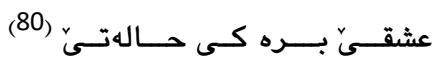

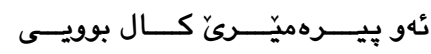

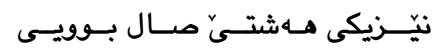

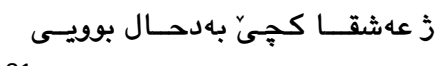

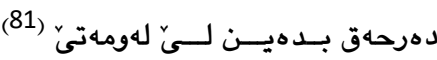

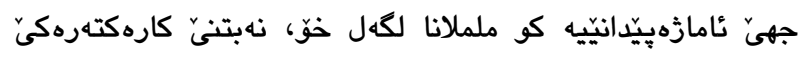

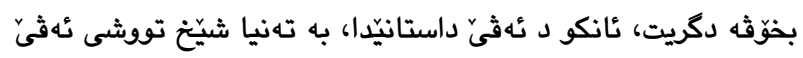

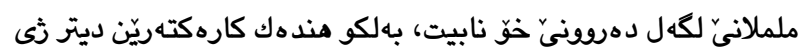

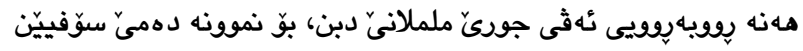

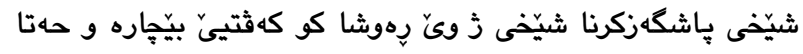

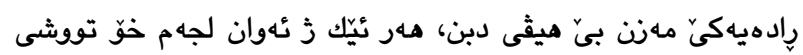

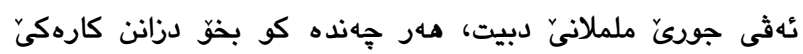

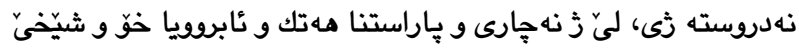

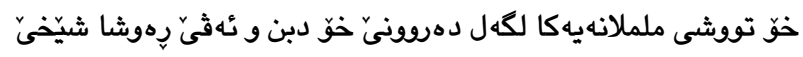

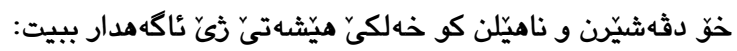

شيّوهيى كو حهز دكهن بهينّه ديتن. بيّى ماسكيّن كوّمهلآيهتى ييّن

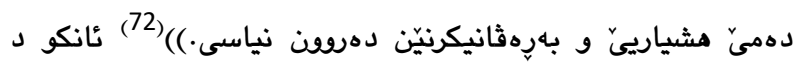
خهونيّدا مروّث تهواو يَّ ئازاده د كاروكرياريّن خوّ دا و بيّى هيّج جوره سانسوّر، شهرم، قهيد و بهنديّن ئايينى، جثاكى و... متد ـ كهواته ليّره

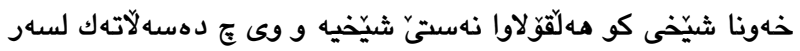
ويَّ نينه، خوياكهرا ئهوان حهزيّن عهمباريوويى و پِاشخستيه كو د د

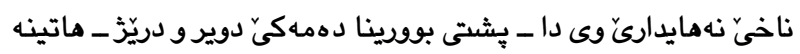

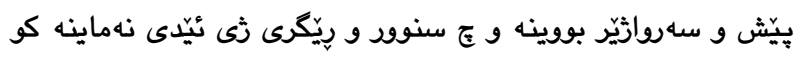
شيخخ ثَّ شهرم بكهت، بهلكو مهزنترين حهز و ويستا وى تيّركرنا خواستهكين خو يِين كيكرينه، كو ب مهموو ويِرهكى، ئازادى و

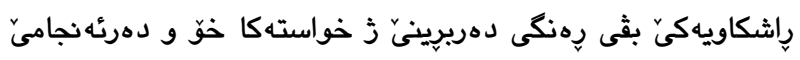

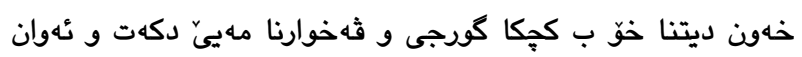

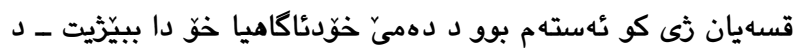

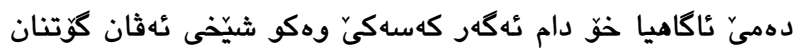

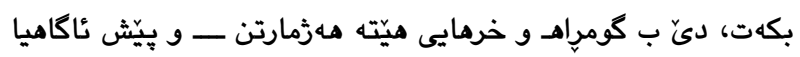

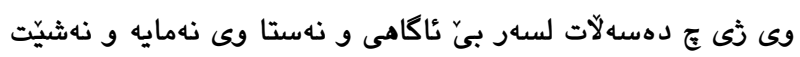

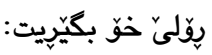

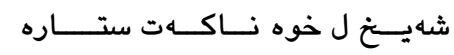

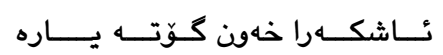

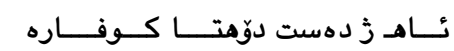
(73)

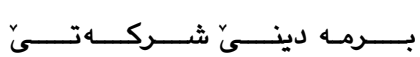

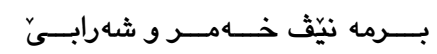

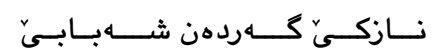

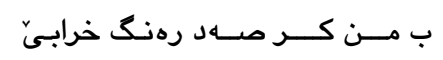

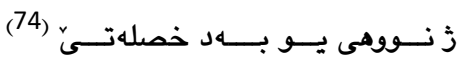
كـافـــر كـــرم مهيــــــوهر كــرم

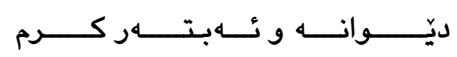

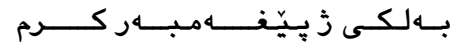

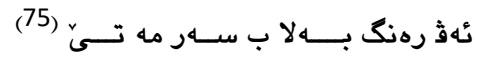
ديسان د بهردهواميا ئه ثيّ ململانا دهرونيا شيخى لكهل خوّ دا، شيّخ

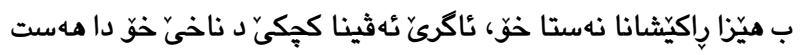

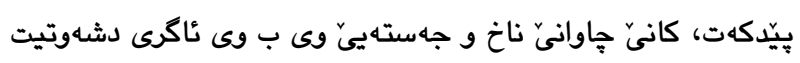

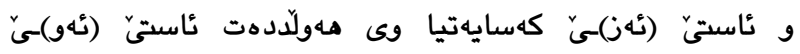
كهسايهتيا وى رام و لغاث بكهت و لسهر زالّ ببيت، بهلآم نكاريت ب

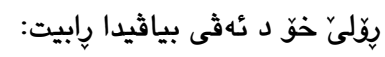

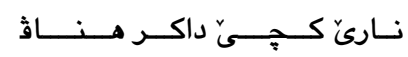

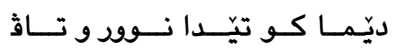
عهكســا تئيـلاهى مـــاتــه نــاث 


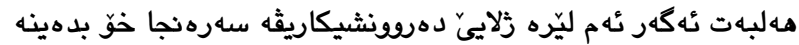
ئه فيّ كريار و سهرهدهريكرنا سوّفيان، وهكو ئه م دبيّزَين ذ سنووريّن

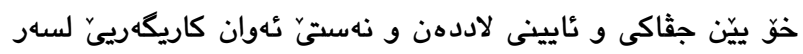

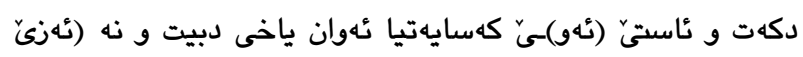

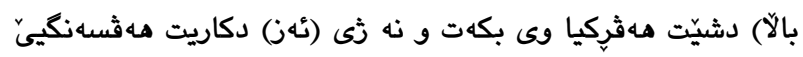

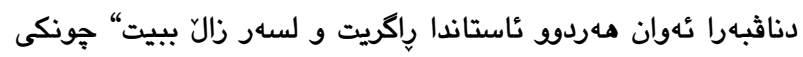

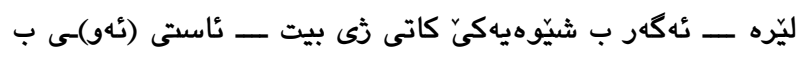
دلىّ خّو دكهثيت و د ئهثى بياثيدا شهرم و سنووردارى نهشيّن

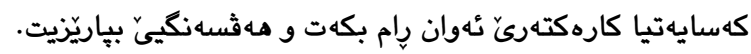

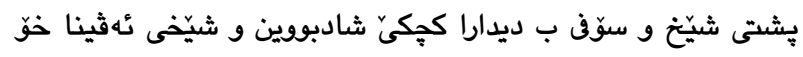

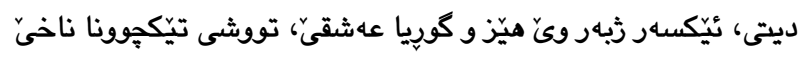

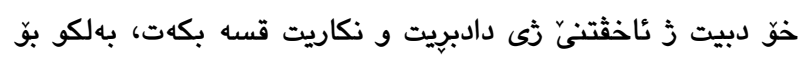

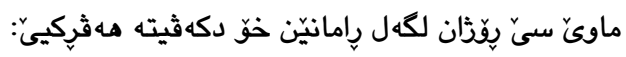

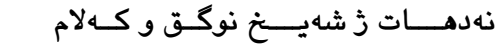
(90)

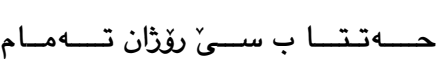

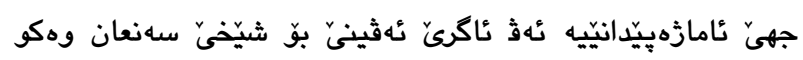

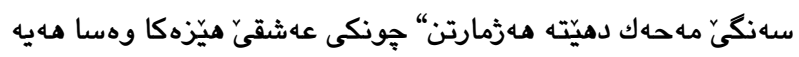
كو راستيا مروّثان خويا دكهت و (نهفسى دشكينيت و خاكى دكهت،

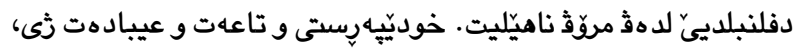

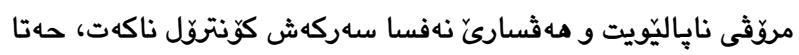

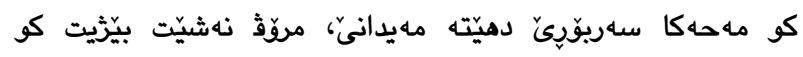
خهوشيهك لجهم وى مهيه يان نه، لهورا عهشق باشترين ئهزموونه تاكو

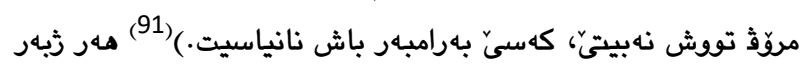

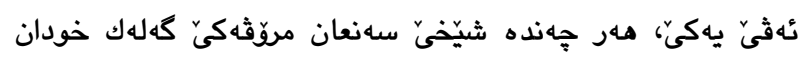

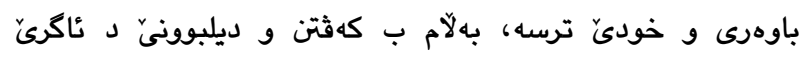

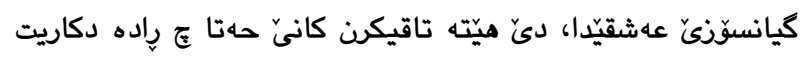
خو لبهر ئهفي نئهموونا توند و دثوار بكريت و ب كيّشانا دهرديّ

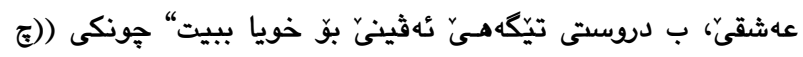

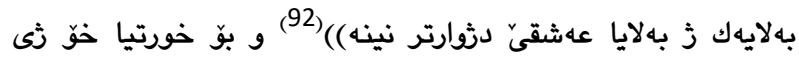

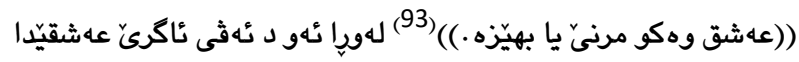

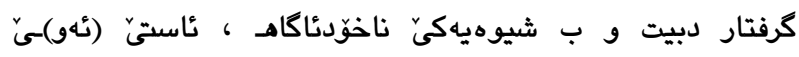

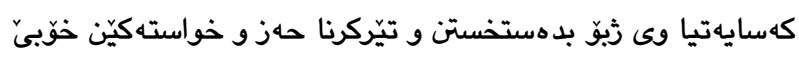

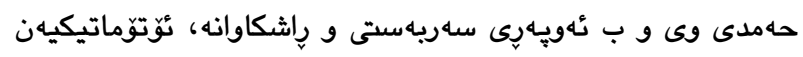
دفويرييّت و د ئه فى بياثيدا دبيّزيتيت:

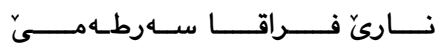

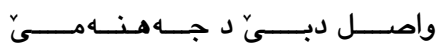

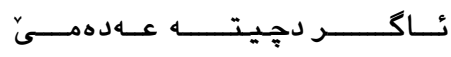

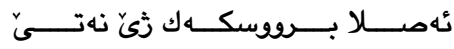

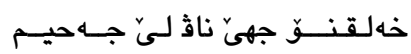

دهرحهق بـدهيـن تج تــى مهيـهـ نـــاخـوَت ل شهايخ ئهث قصصهيه

كـويكـهين بدهست باخـوىي مهيـــ (82)

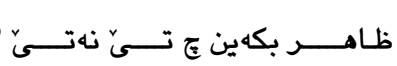

ئظهار بكـهــن بــهـ دنـــامــى يه

دهرحهـ بدهيـن بــى طـامسى يه

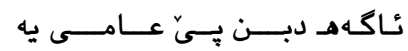

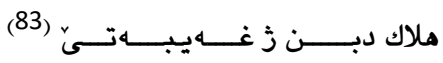

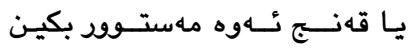

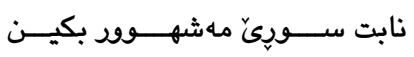

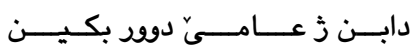
(84) .

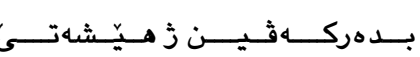

كــويكيــن ل مـــهـ لازم بـوويه

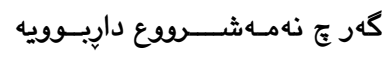

دهرمــان نهجس بت مهعفــويه

(85)

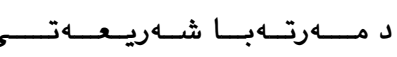

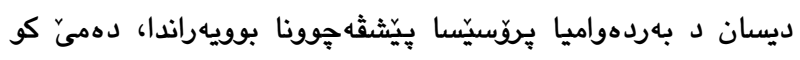

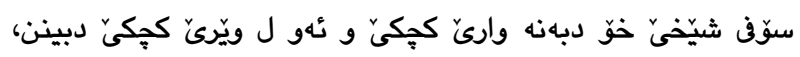
جارهكا دى ململانهيهكا دهرونى لجه م سوّفيان دروست دبيت كو ئهو

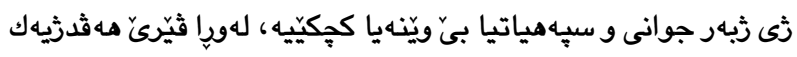

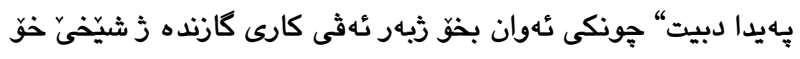

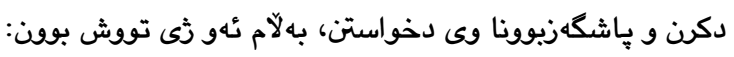

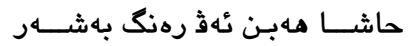

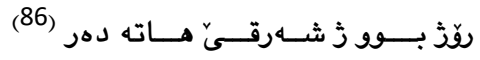

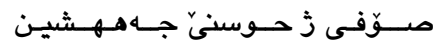

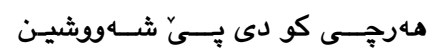

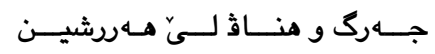

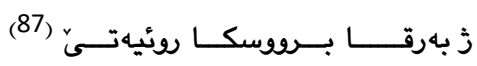

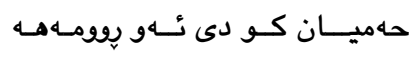

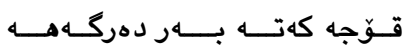

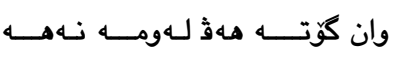

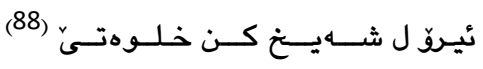
سنك ئهبيهضـا غـونتِّه ل سـهر

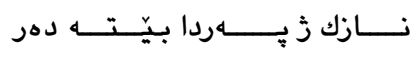
لــي ديــن دبــن صـــاحب نهظهر

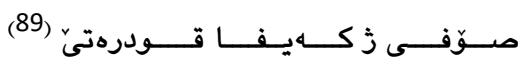




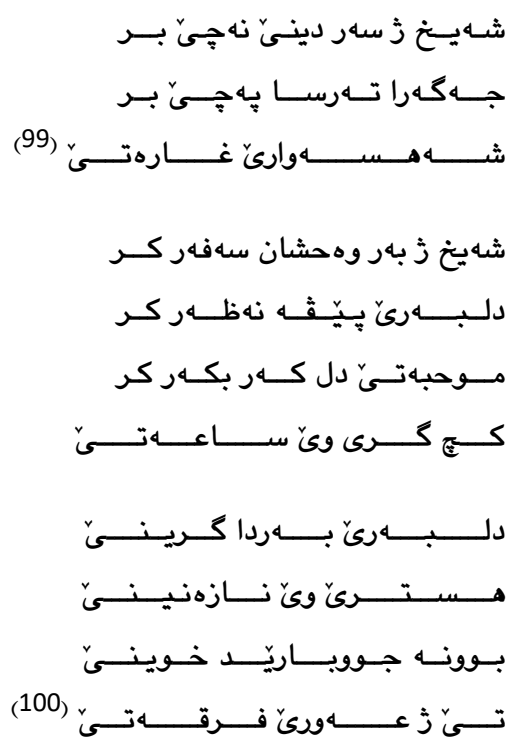

ههر وهكو ليّره بو مه خويا دبيت، ململانهكا توند و دثوار دناقبهرا

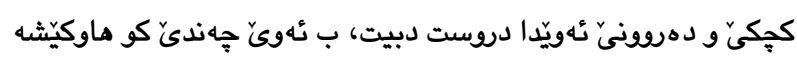

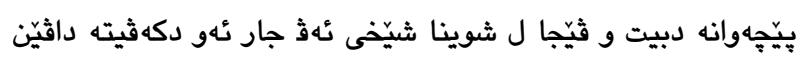

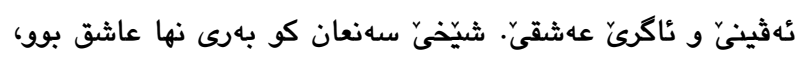

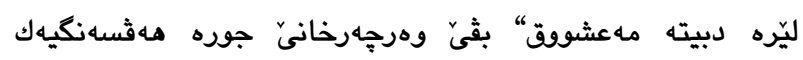

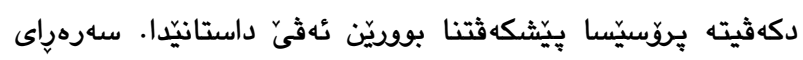

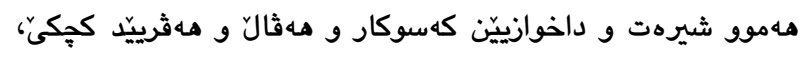

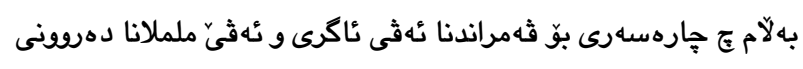

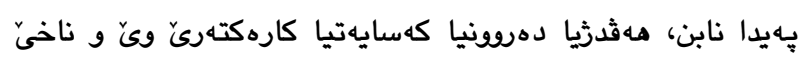

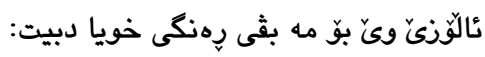

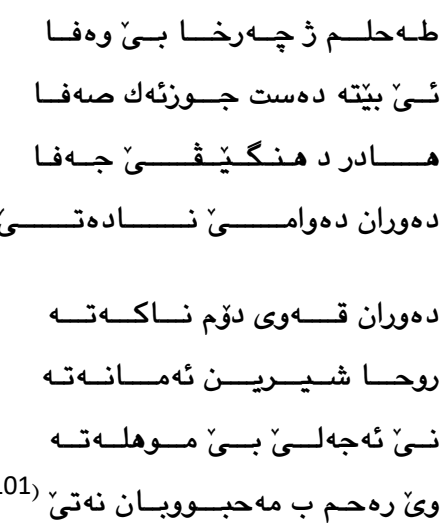

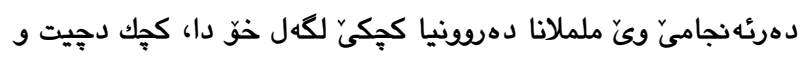

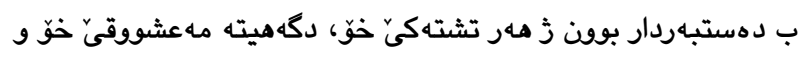

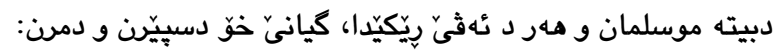

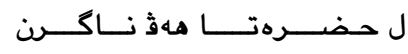

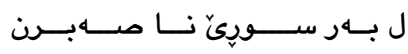

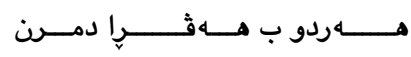
(102)

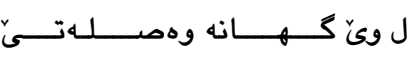
زوهصلـهنتـا حــالــك وه دى

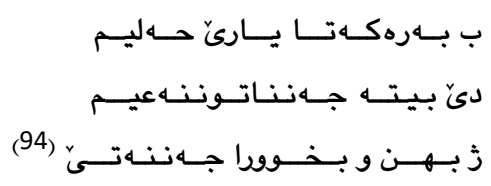

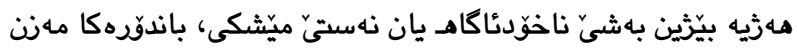

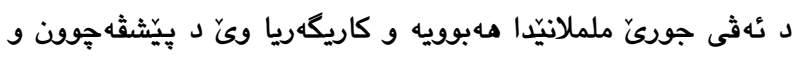

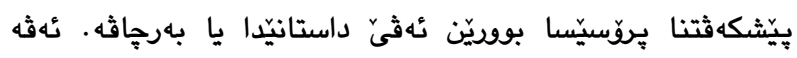

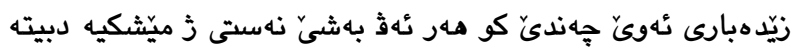

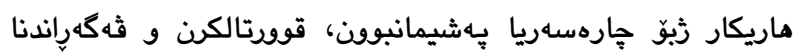

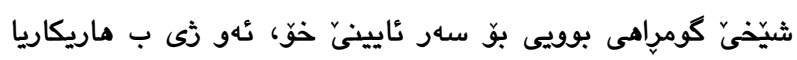

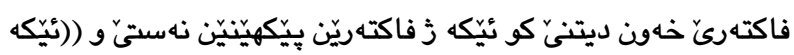
ذ بهرجافترين و خوياكهرترين كليليّن شيكردنهوهيا لوغزا دهرونى و و

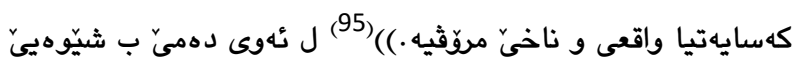

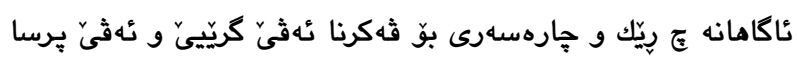

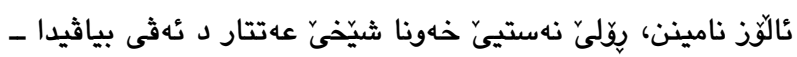

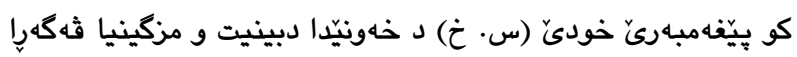
شيّخى ددهت - يَّ خويا و وهرجهـرخانيه:

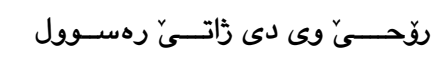

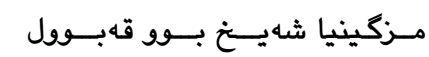

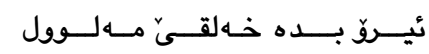

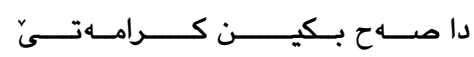

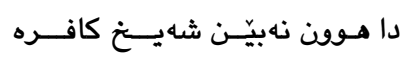

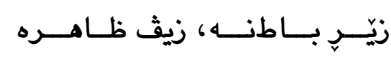

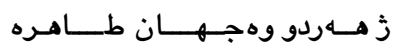
(96) .

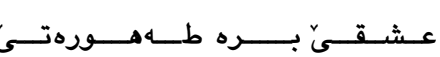

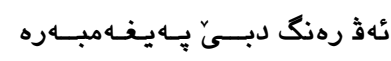

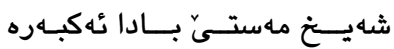

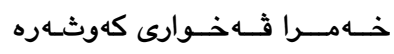

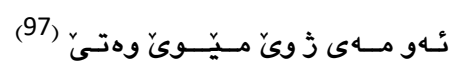
ئهو حــورييــا شـهــــن بـــابهته

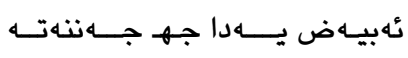
لهب شهككــهرا نــهى قـامــهـه

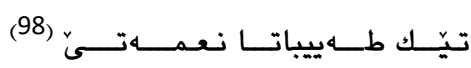

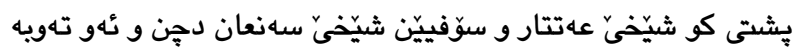

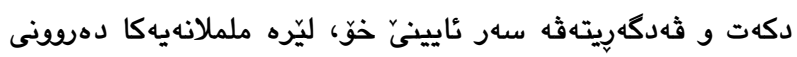

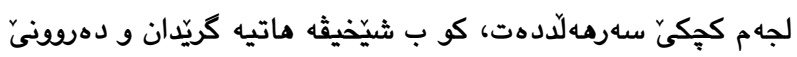

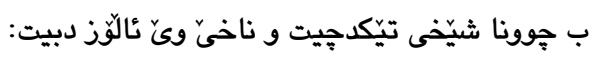

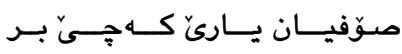




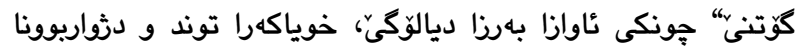

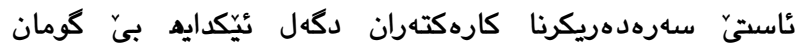

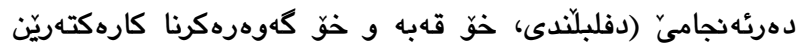

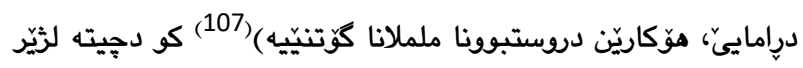

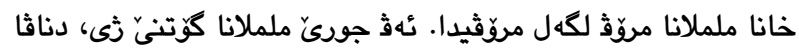

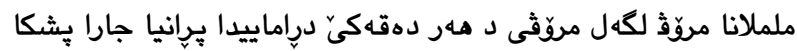

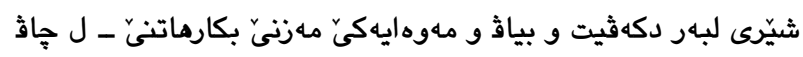

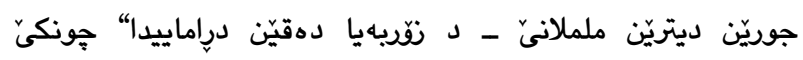
زلايهكيثه يا كريّداييه ب مهبوونا توخمى كارهكتهران و زلايهكيّ ديتر

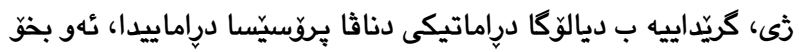
ثى جورهكيّ مهره كرنكيّ توخمى ململانا دراماتيكيه.

3.1.2.2. ململانا جهستهيى (Physical Conflict): بيّ

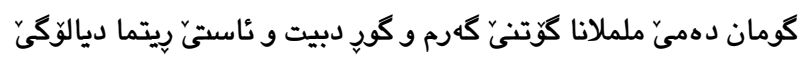

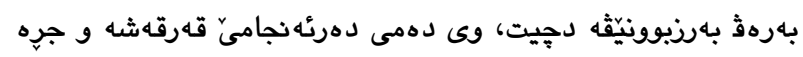

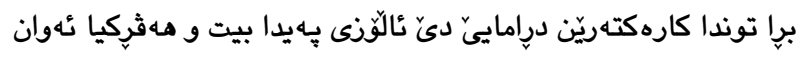

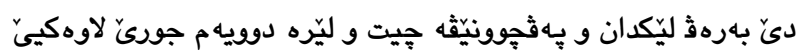

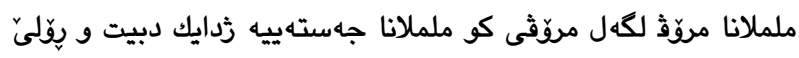

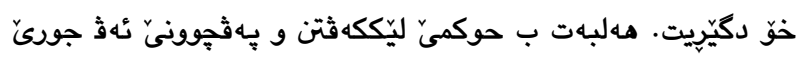

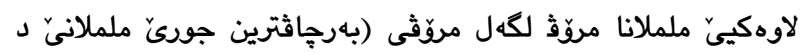

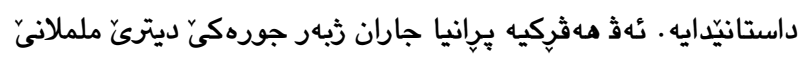

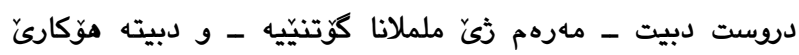

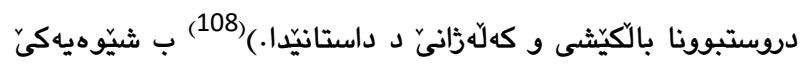
كثتى تئهثه سهبارهتى ململانا مروّث لكهل مروّثى و جوريّن لاوهكيِين

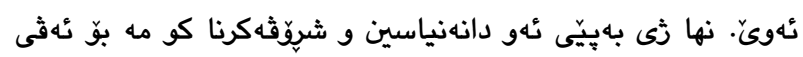

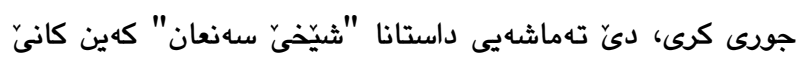
حهتا ع راده ئهث جوره تيّدا ههيه و بهرجهاسته دبيت.

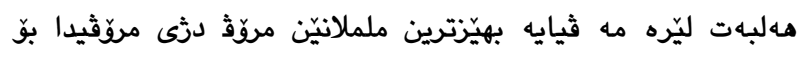

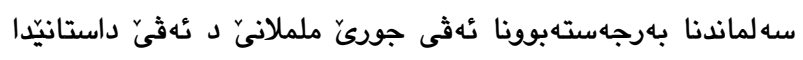

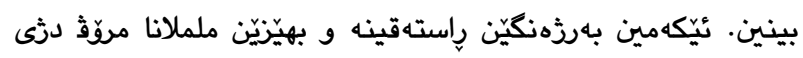

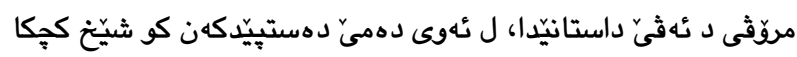
كورجى د خهونيّدا دبينيت، پِشتى هنگى شهيدا و سهوداسهر دبيت و دكهثيته د خهلويّدا، بهرجهسته دبن. دهميّ سوّفيِين شيخّى داخوازا وكّ جههنديَ ثى دكهن بههثرا وهكو جاران دهست ب زكر و تاعهتى

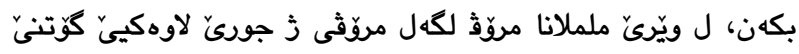

بهرجهاسته دبيت:

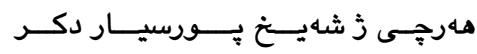

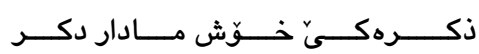

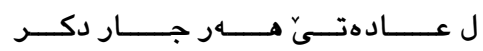

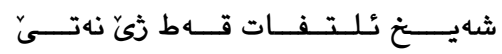

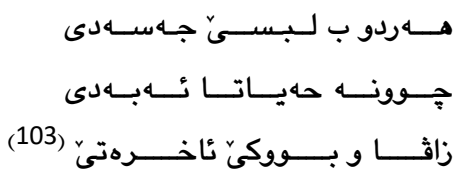

كهواته بهرهه م و دهرئه نجامي ئهثى ململانا شيّخى و كِكا كورجى، موسلمانبوونا دوويارهيا شيّخى و ئيمان ئينان و موسلمانبوونا كهِ مهسيحى، مهروهما ثادبوون بوو ب كهمشتنا مهث و مرنا تئهان

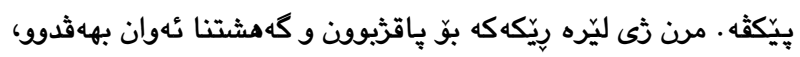

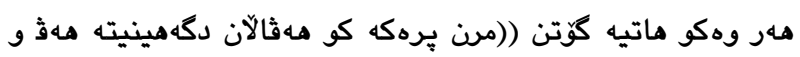

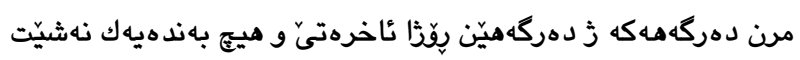

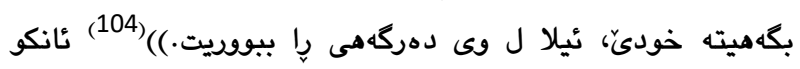

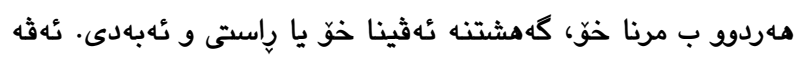
سهبارهتى هـبوون و بهرجهستهبوونا جوريّ ململانا هه ثدرًا دراماتيكيا

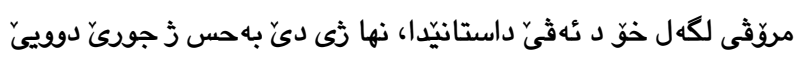

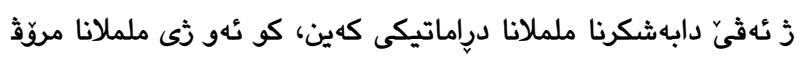

لكهال مروقيه.

3.1.2. ململانا مروّث دثى مروّثى (Man against man)

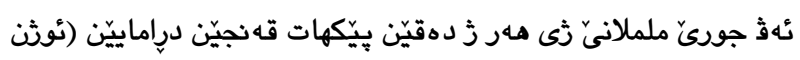

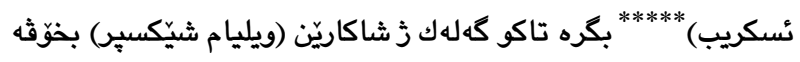
دكريت. ئه جوريّ ململانا دراماتيكى بهربـلآثترين جورىگ ململانيّيه د

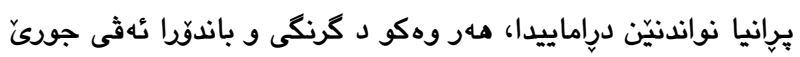

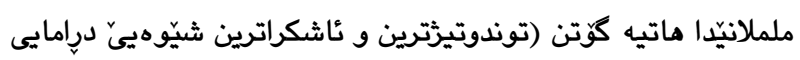

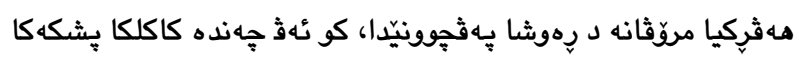

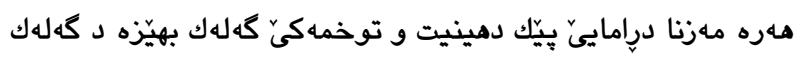

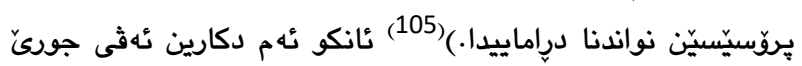

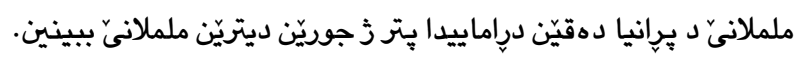

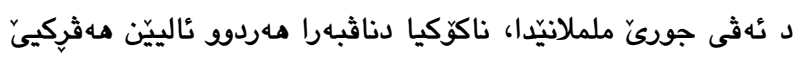

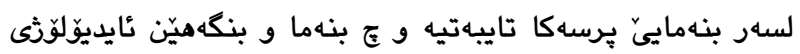

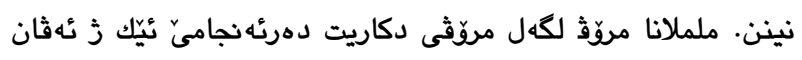

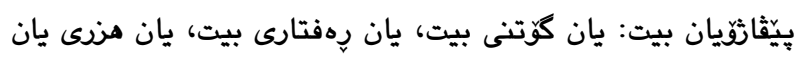

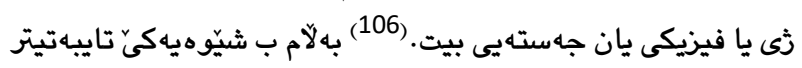

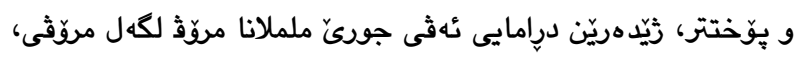

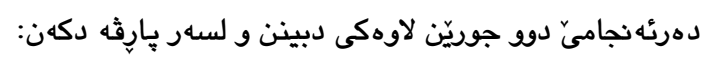

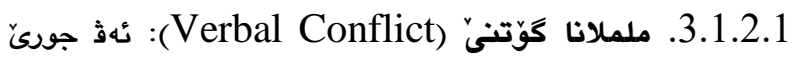

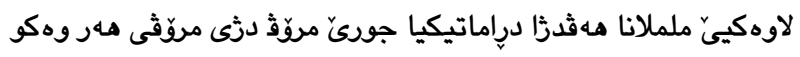

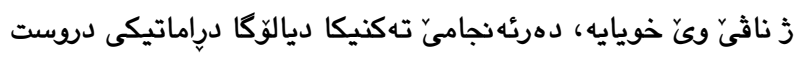
دبيت. ل نئهى دهميّ كو كارهكتهريّن درامايىّ دكهثنه بهرامبهرى

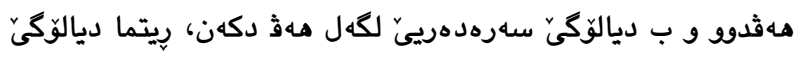

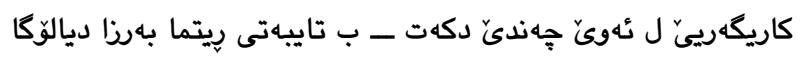

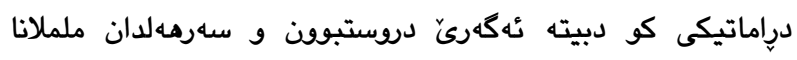


(113)

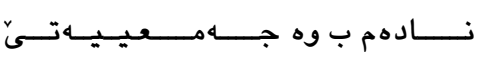

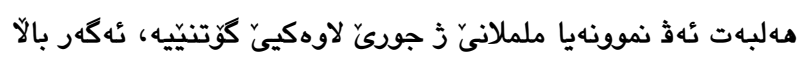

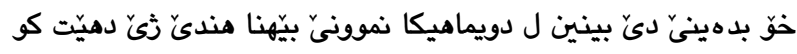

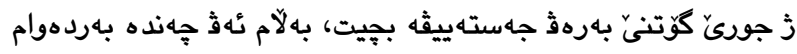

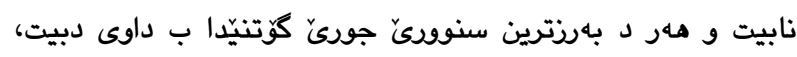

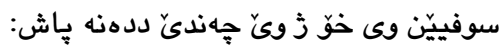

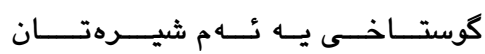

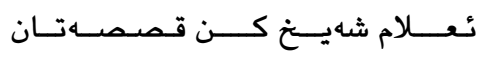

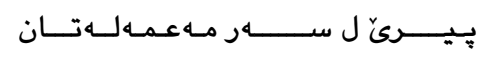
(114)

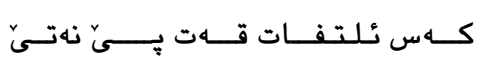

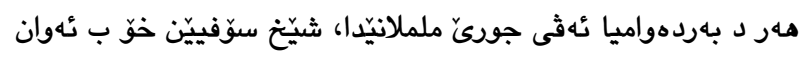

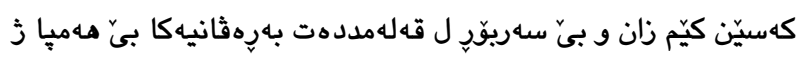

ئهثينا خَو دكهت و دبيّزيته ئهوان:

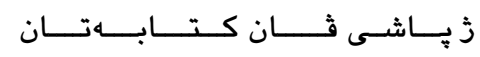

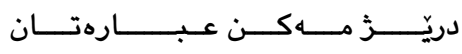

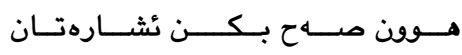

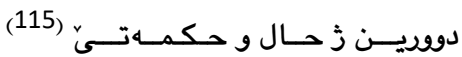

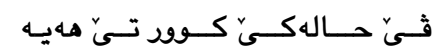

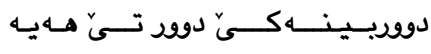

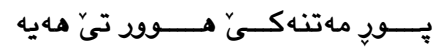
(116)

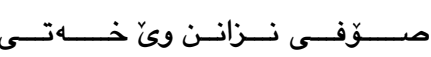

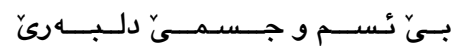

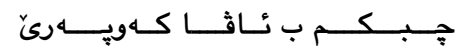

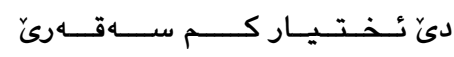

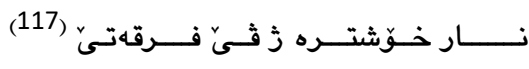

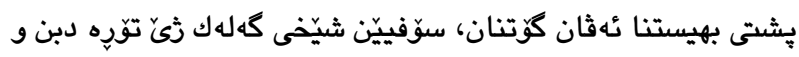

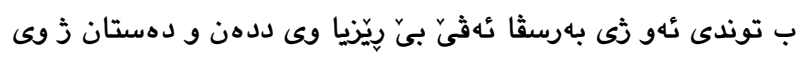

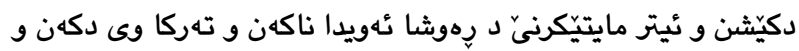

دميّلنه ويَرىّ:

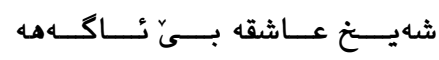

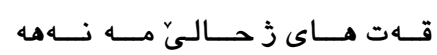

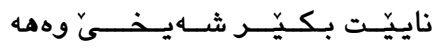

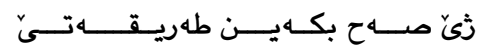

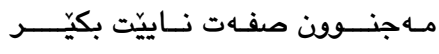

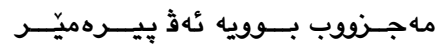

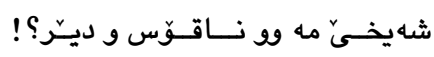

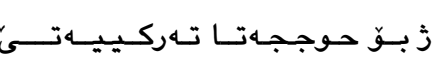

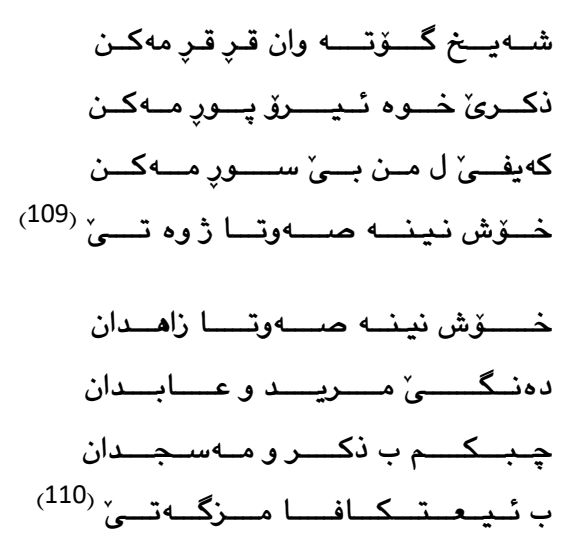

كو مهر وهكو ذ شيوّثَكرنا نموونى بوّ مه خويا دبيت، ليّره شيّخى

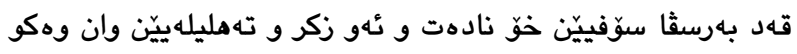

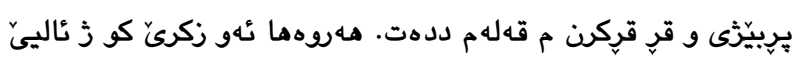

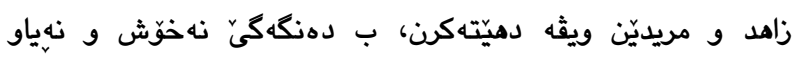

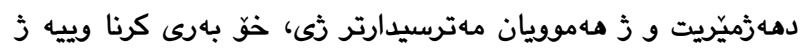

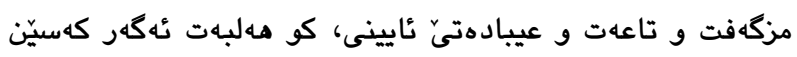

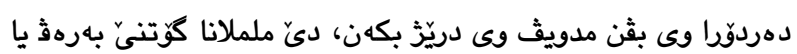

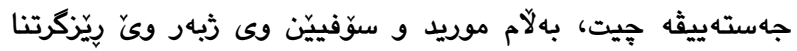

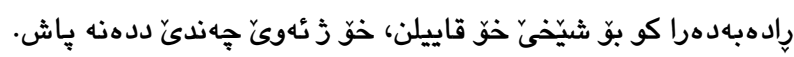

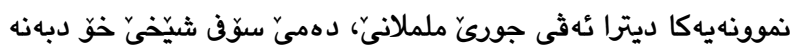

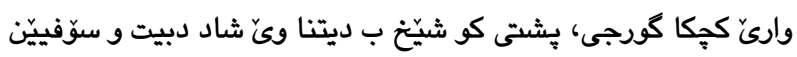
وى ثىى دخوانت ئيّدى ته ئهو ديت و وهره دا ثهكَرين و ئه و وئهو نه وهكو هـثين، شيّخ ب توندى بهرسثا ئهوان ددهت و ههموو سنووران

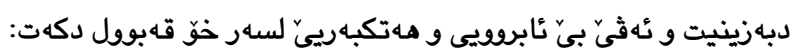
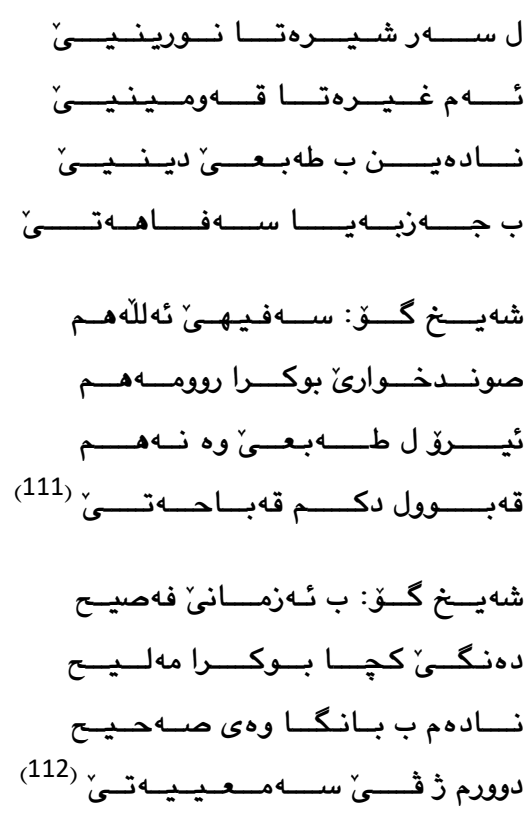

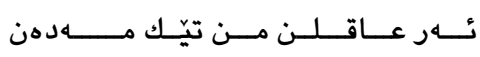

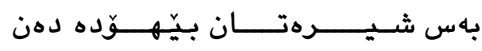

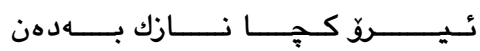


كارهكتهرهكي بناشي (ثيخخي عهتتار) كو د داستانيّدا ب خهليفه

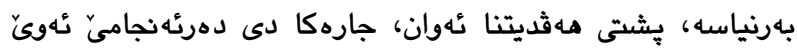

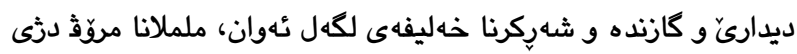

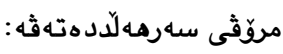

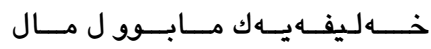

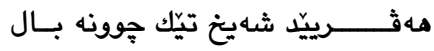

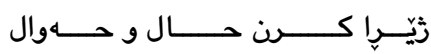
(124) v

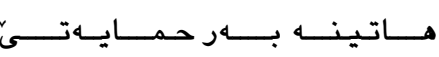

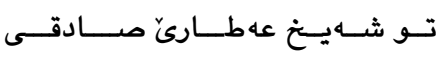

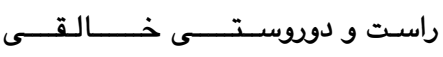

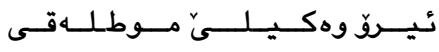

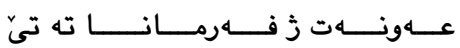
شهـيـخ خــوّته وان صـاحب ســورا

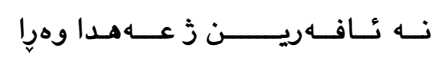
قيَمـيِش نهبوفن ب شهيخَّ خـوهرا (125) v

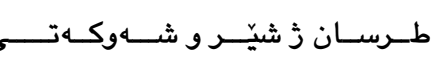

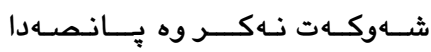

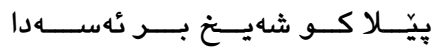

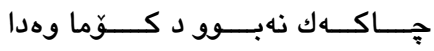

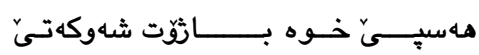

$$
\begin{aligned}
& \text { خـوّ مـــوون حهـــى بيّكيّر نهبوون }
\end{aligned}
$$

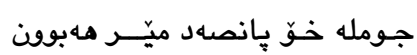

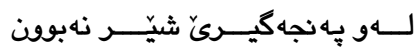

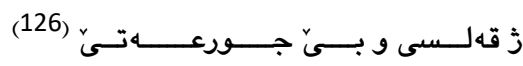

دويماهيك نموونهيا بهرجاث و بهرجه ستهيا ململانا مروّث درّى مروّقى يا

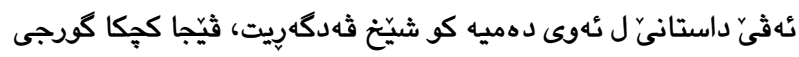

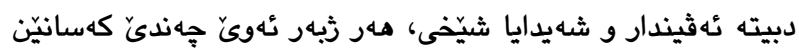

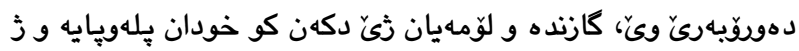
مالَّاتهك باش و... هتد، بهلآم مهثركى دروست دبيت و كجّك ب توندى

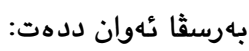

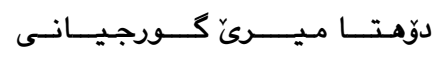

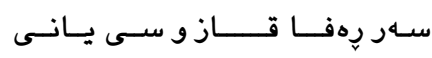

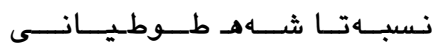

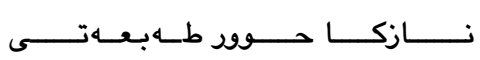

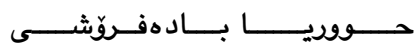

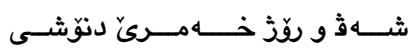

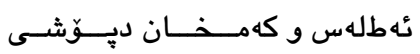

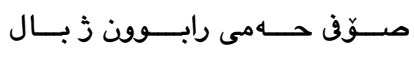

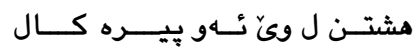

$$
\begin{aligned}
& \text { حهميـــان ل ســهر دينـــ به طـال }
\end{aligned}
$$

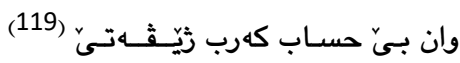

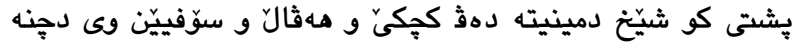

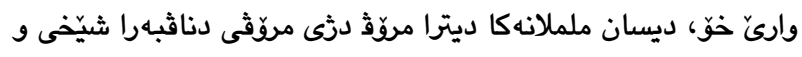

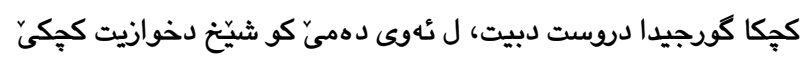

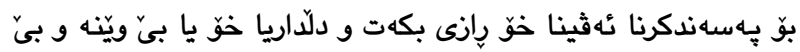

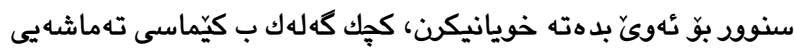
وى و داخوازيا وى دكهت:

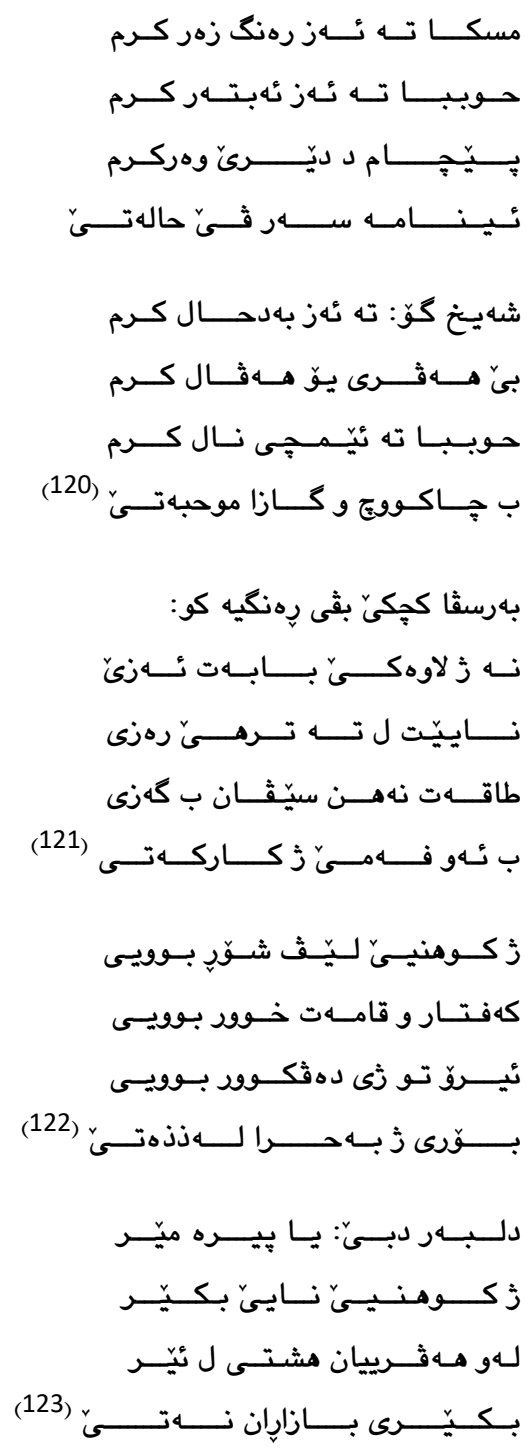
دهرئه نجاميَ ئهثان شكاندن، كِّ داخوازيَّ ثَّ دكهت هـر جوره

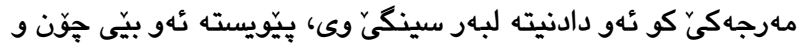

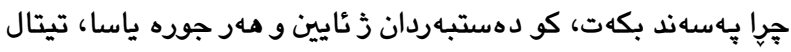

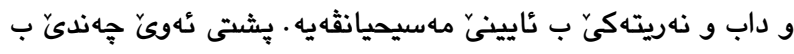

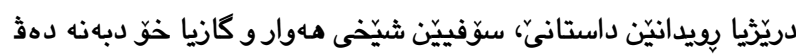




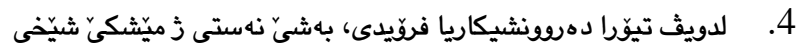

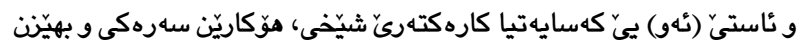

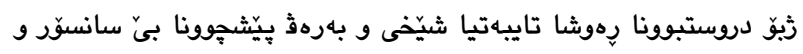

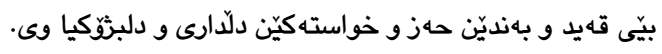

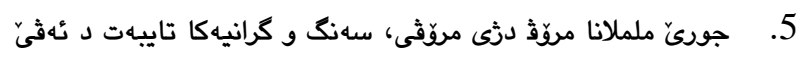

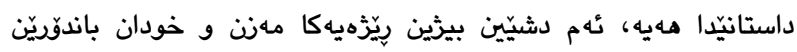

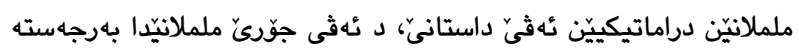
كبن.

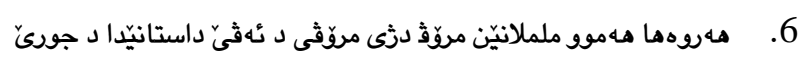

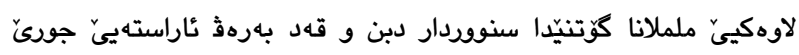
لاوهكيى ململانا جهستهيثه ناجِن.

\section{5. بهراويزّ}

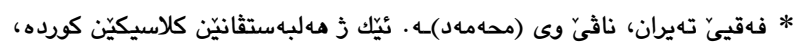

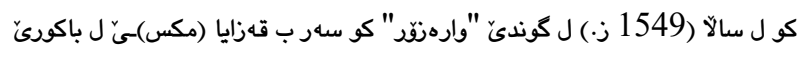

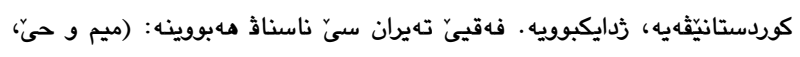

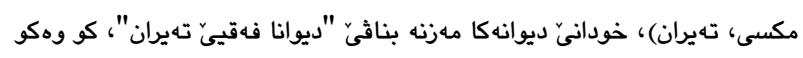

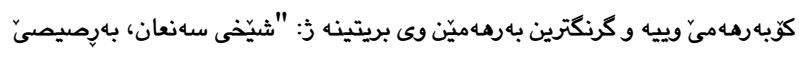

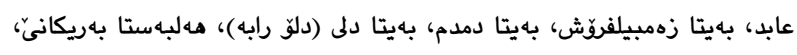

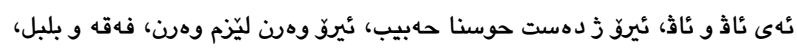

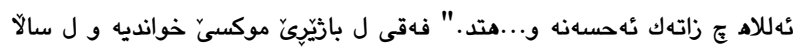

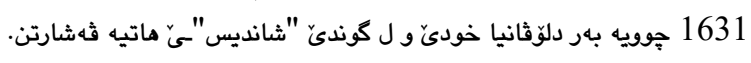
ثَيّدهر:

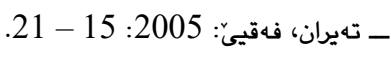
1. El- Ezabi A. Y. 1980. p 139.

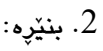

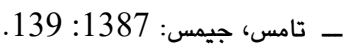
- عيد، الدكتور كمال الدين: 2006: 1387: 104 138.

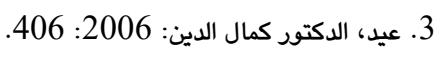

4. 5. داد، سيما: 1385: 385.

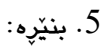

- ئيبراهيمى، عهبدووللا : 2012: - روحانى، ماجد مردوخ: 1387 : 2004: 201 201 : 1891.

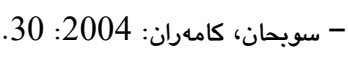
- قاضى، حافظ: 2005: 346 - 340

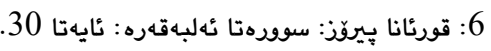
7.

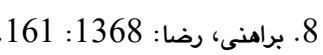

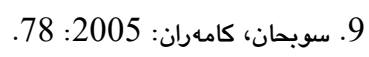
10. سويحان، كامهران: 11 11. مكى، ابراهيم: 1383: 185: 185 12. سالار، ئه حمهد: 11 12005: 103 1383: 103.

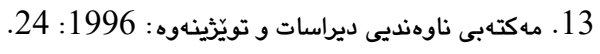

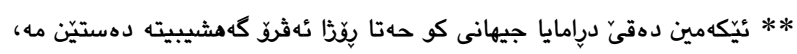

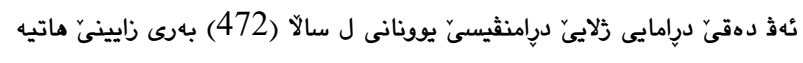

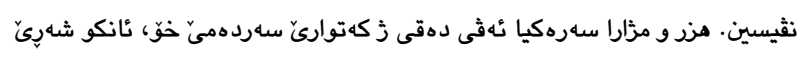

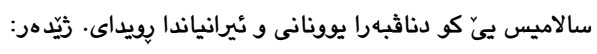

(127)

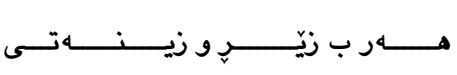

$$
\text { خهملا خـوه ديســان كــار بكـه }
$$

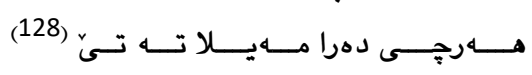

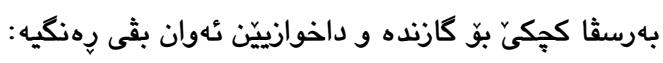

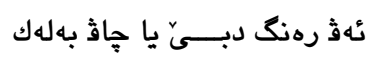

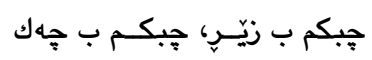

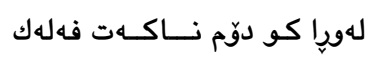
(129)

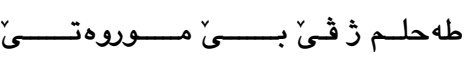

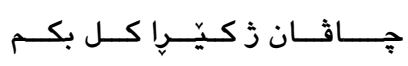

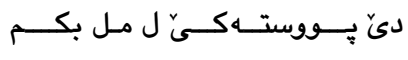

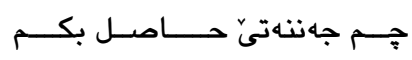

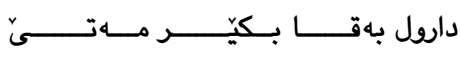

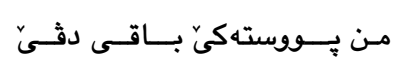

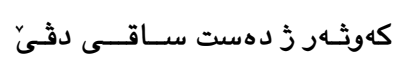

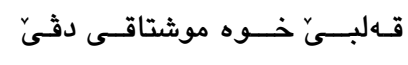

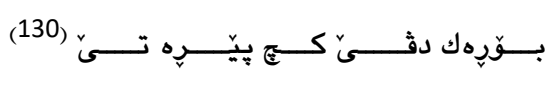

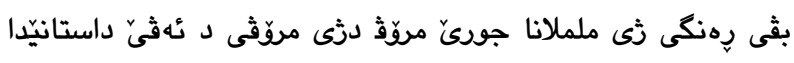

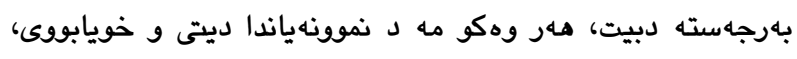

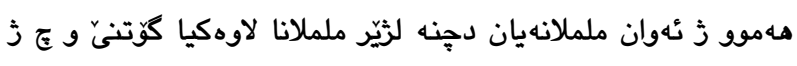

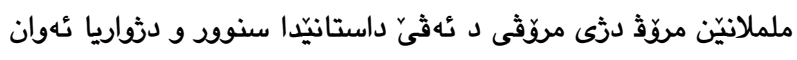

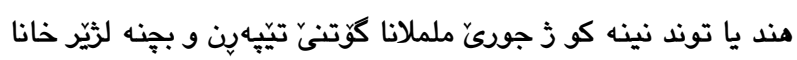
ململانا لاوهكيا جهستهيى.

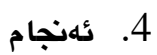

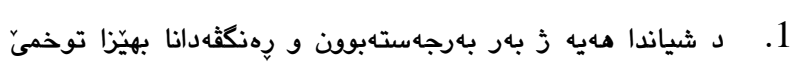

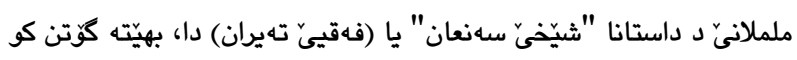

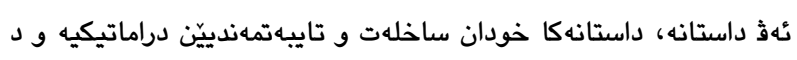

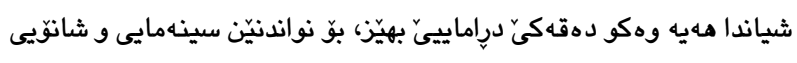

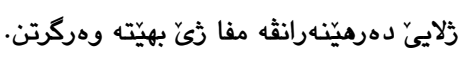

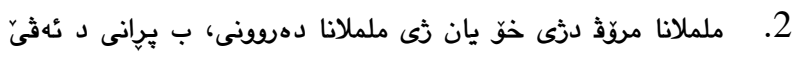

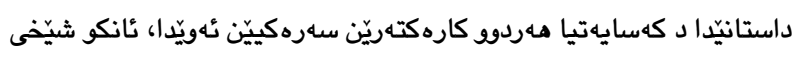
و كجّا كورجيدا بهرجهاسته دبيت.

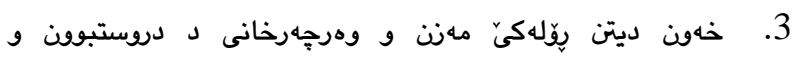

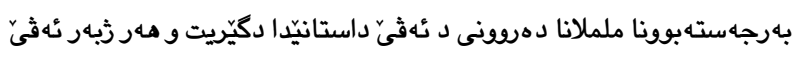

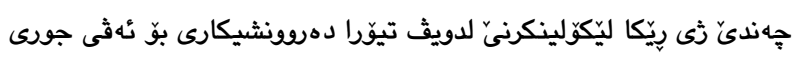

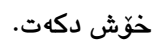


50. العنبرى، خالد بن على: ؟: 121.

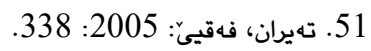

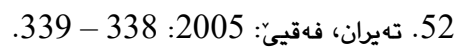

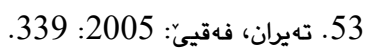

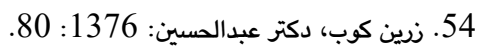

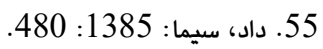

56. ماشمى، رقيه و پِورنامداريان، دكتر تقى: 1385: 1391.

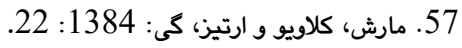

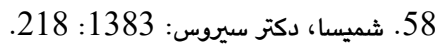
59. ويّيستيّر، راجيّر: 2006: 2006: 167.

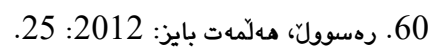

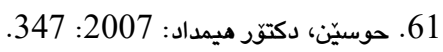
62. شميسا، دكتر سيروس: 63. 1383: 219: 219.

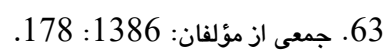

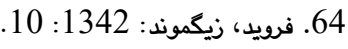

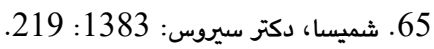

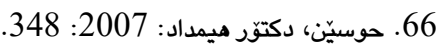

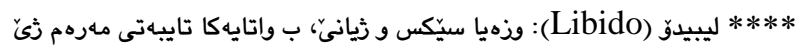

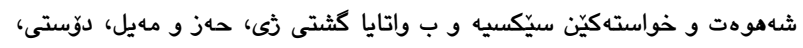

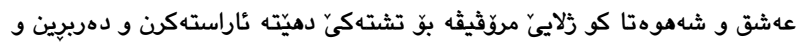

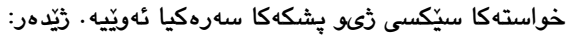
- فرويد، زيكموند: 1343: 9 - 10 - 10 - 10.

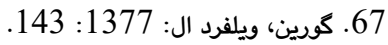

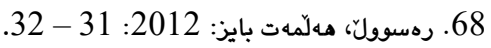

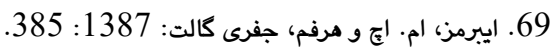

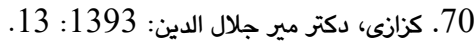
71.

72. وايس، له لم: 1378، 13: 47. 73. تهيران، فهقيىّ: 2005: 346

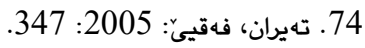

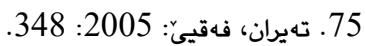

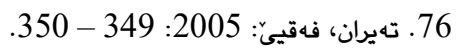
77. تهيران، فهقيىّ: 2005: 360

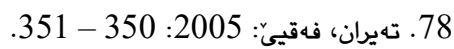

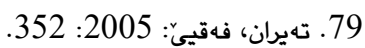

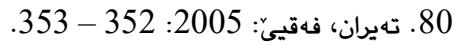

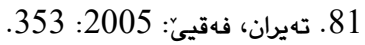

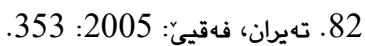

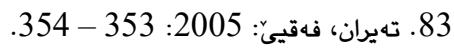

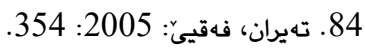

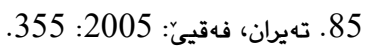

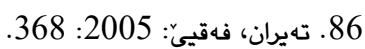

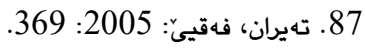

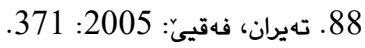

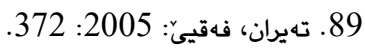

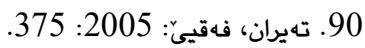

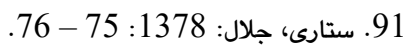

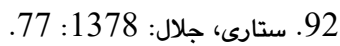

- ملشينكر، زيكفريد: 1366 14: 14.

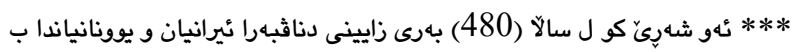

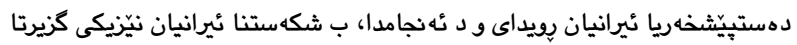

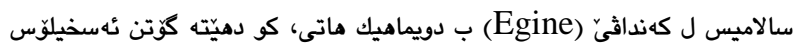

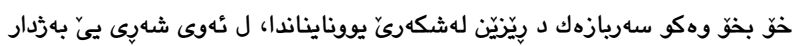
بوو. ثَيْدهر:

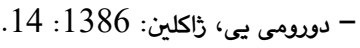

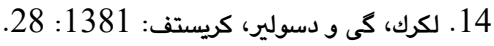

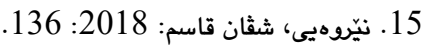
16. رضايی، عربعلى: 1382 138

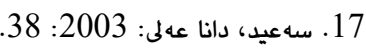
18. سوبحان، كامهران: 1904 2004: 30. 19. عيد، الدكتور كمال الدين: 2006: 206 2004. 406.

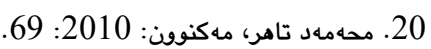

21. آدلر، استلا: 1387 مهاده تاهر، مهنون: 131.

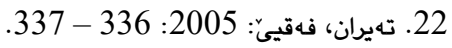
23. باكثير، على احمد: 1964: 196 : 24

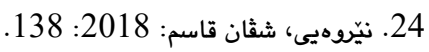

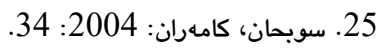
26. محرابى، رحمت الله: 1372: 88 : 87.

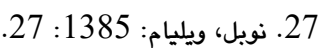

28. داد، سيما: 1385: 385.

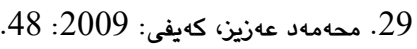

30. مكى، ابراهيم: 1383: مدهاد عهزيز، 187.

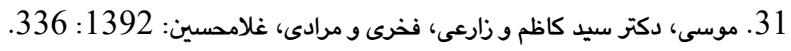

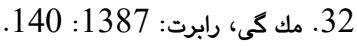

33. مك گیى، رابرت: 1387 مك رابرت: 140

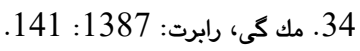

35. حنيف، محمد: 34 مكى رابرت: 1384: 49.

36. الزيادات، الدكتور تيسير محمد: 135 : 2010: 118 : 118. 37. بنيّره:

- مكى، ابراهيم: 1383: 130 190 - 199. - - تامس، جيمس: 1387: 139. - اخرى، لاجوس: 1383 : 226 ـ 241. 38. بنيّره:

- مكى، ابراهيم: 1383: 1384: 194.

- بِورعمرانى، روح الله مهدى: 1386 : 169 : 169.

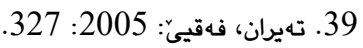

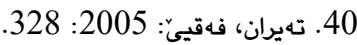

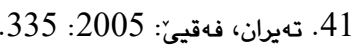

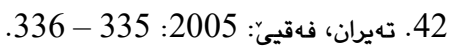

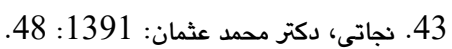

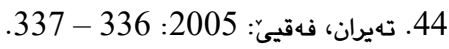

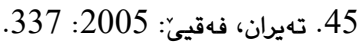

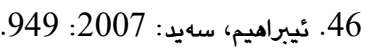

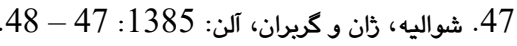
48. كوير، جى سى: 1379 137 : 225. 49. شوان، نيبراهيم ئه حمهد: 2010: 203. 
ئيبراهيم، سهيد. 2007. خهونامهى كوردى. وهركيّرِانى: رزكار كريم. ناوهندى

$$
\text { روّشنبيرى سليَمانى. سليّمانى. }
$$

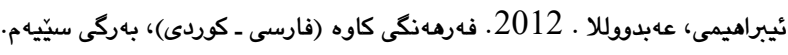

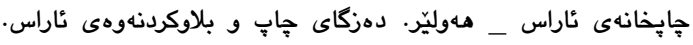
هـوليّر

تهيران، فهقييّ. 2005. ديوانا فهقينّ تهيران. كوّمكرن و تويرًاندن: سهعيد

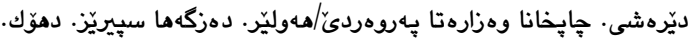

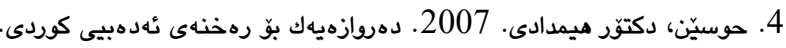
جإِخانهى خانى/دهوّك. دهزكاى موكريانى. هـوليّر.

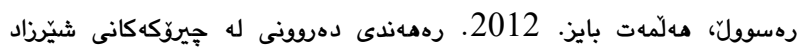
حهسهندا. جإِخانهى موكريانى. دهزكاى موكراينى. هـوليّر.

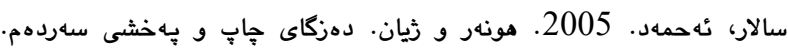
سليّمانى. سوبحان، كامهران. 2005. شانوّ و ناسنامه. دهزكاى جاٍ و پِهشى سهردهم. سليّمانى.

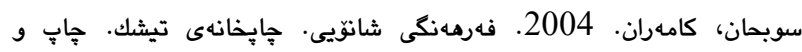
بلاوكردنهوهى وهزارهتى يِّشنبيرى. سليّمانى.

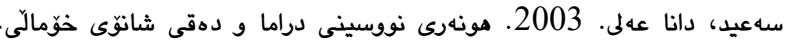

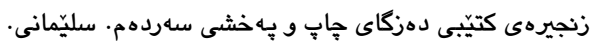

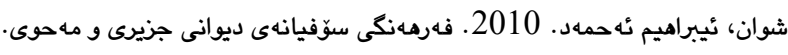

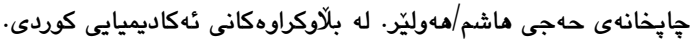
هـوليّر.

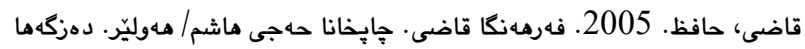

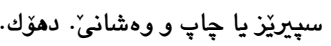

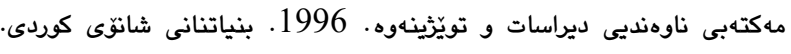

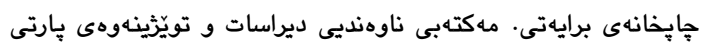
ديموّكراتى كوردستان/مهكتهبى سيايى. هدوليّر. محهمهد تاهر، مهكنوفن. 2010. ديالؤك د درامايا كورديدا ــ دهثهرا به هدينان

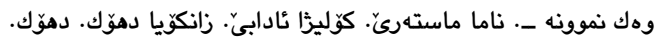

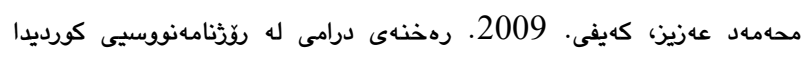

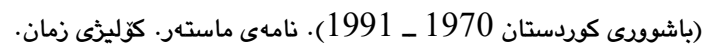
زانكوّى سهلاحهددين. هـوليّر.

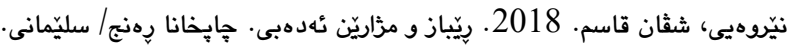
ذروهانيّن بـهرتووكخانا خانى. دهوّك.

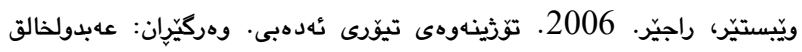

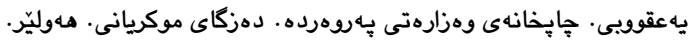

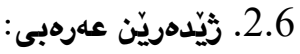

باكثير، على احمد. 1964. فن المسرحية من خلال تجاربي الشخصية. دار المعرفة. قاهرة. الزيادات، الدكتور تيسير محمد. 2010. توظيف القصيدة العربية المعاصرة لتقنيات الفنون الاخرى. دار البداية. عمان. عيد، الدكتور كمال الدين. 2006. اعلام والمصطلحات المسرح الأروبي. دار الوفا لدنيا للطباعة والنشر. الأسكندرية.

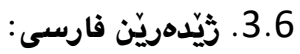
اكرى، لاجوس. 1383. فن نمايشنامه نويسى. جֶإخانهى نوبهار. انتشارات نكاه. تهران.

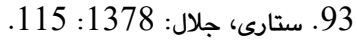

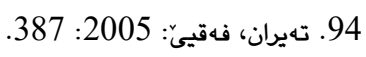

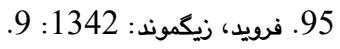

96. تهيران، فهقيىّ: 2005 2005:

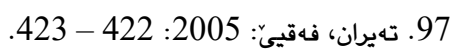
98. تهيران، فهقيىّ: 97. تهيران، فهيى: 2005: 423.

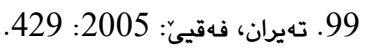

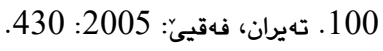

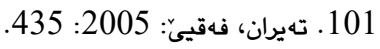

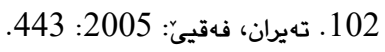

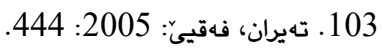
104. ستارى، جلال: 1378 13 : 119 . 1103

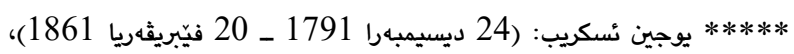

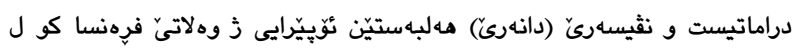

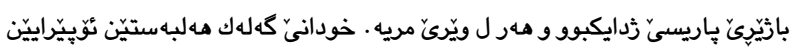

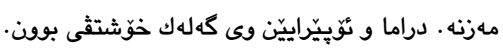

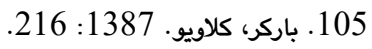

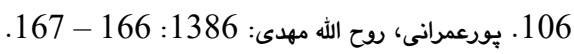

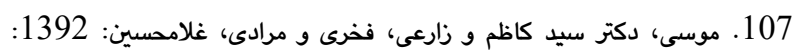
.344

108. موسى، دكتر سيد كاظم و زارعى، فخرى و مرادى، غلامحسين: 1392: .345

109. تهيران، فهقيىّ: 2005: 110 340

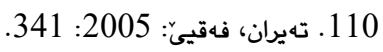

111. تهيران، فهقيى: 2005: 377 : 3710

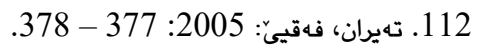

113. تهيران، فهقيىّ: 2005: 112

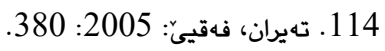

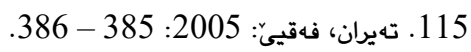

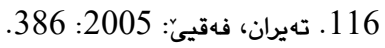

117. تهيران، فهقيى: 116

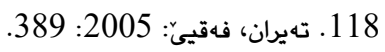

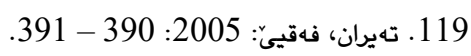

120. تهيران، فهقيىّ: 2005: 119

121. تهيران، فهقيىّ: 2005: 2005: 2005: 2005.

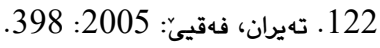

123. تهيران، فهقيىّ: 2005: 2005: 399.

124. تهيران، فهقيىّ: 2005: 2005: 414

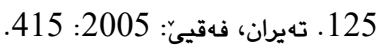

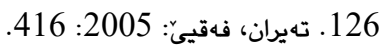

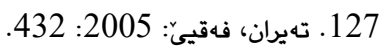

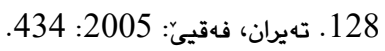

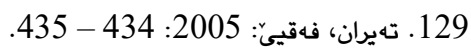

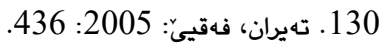

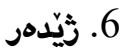

1.6. ثيّدهريّن كوردى: 
كزازى، دكتر مير جلال الدين. 1393. وخشور ايران. جֶإِخانهى مهارت. انتشارات معين. تهران كوير، جى سى. 1379 ـ فرهنگ مصور نمادهاى سنتى. ترجمهى: مليحه كرباسيان. جإِخانهى مهارت. نشر فرشاد. تهران.

كورين، ويلفرد ال. 1377. راهنماى رويكردماى نقد ادبى. ترجمهى: زهران. زهرا ميهن خواه. جإِخانهى مؤسسهى اطلاعات. انتشارات اطلاعات. تهران.

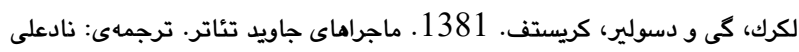
همدانى. هإِخانهى جبارى. نشر قطره . تهران.

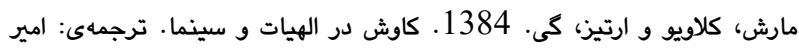

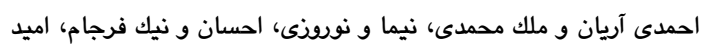

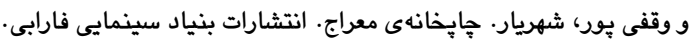
تهران. محرابى، رحمت الله. 1372. آموزش تئاتر. جإخانهى كامران. انتشارات تربيت.

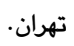

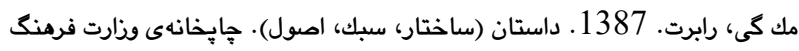
و ارشاد اسلامى. انتشارات هرمس. تهران.

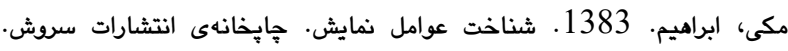
انتشارات صدا و سيماى جمهورى اسلامى ايران (سروش). تهران. ملشينگر، زيكفريد. 1366. تاريخ تئاتر سياسى. جإِخانهى تلك. انتشارات سروش. تهران.

موسى، دكتر سيد كاظم و زارعى، فخرى و مرادى، غلامحسين. 1392. بررسى

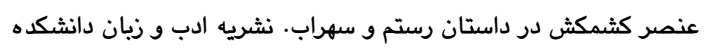

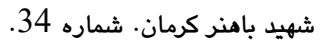
نايت، ديمون. 1388. داستان نويسى نوين. ترجمهى: مهدى فاتحى. جإِخانهى جهان كتاب. انتشارات جشمه. تهران.

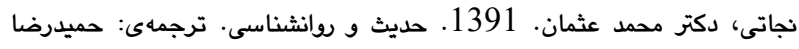

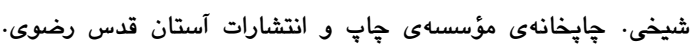
انتشارات بنياد بِثروشهاى اسلامى. مشهد.

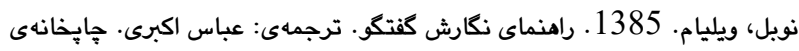
انتشارات سروش. نشر سروش و ادارهى كل بِّروشهاى سيما. تهران. وايس، له له. 1378. تعبير خواب. ترجمهى: دكتر منصور حكيم جوادى. جإِخانهى عروج. انتشارات كيانوش. تهران.

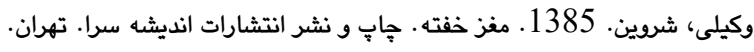

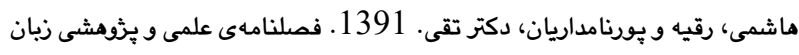
و ادبيات فارسى دانشكاه آزاد اسلامى سنندج. شمارهى دهم.

\section{6. ريّدهريْن ئينعليزى}

El- Ezabi A. Y. _ et.al, Oxford, Oxford university press, England, 1980, p 139.
العنبرى، خالد بن على. تعبير خواب در برتو قرآن و سنت. ترجمهى: صلاح الدين توحيدى. نسخهى الكترونى سايت (عقيده).

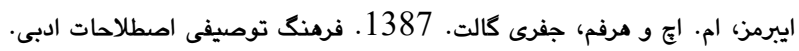

$$
\text { جإِخانهى هاتف. انتشارات رهنما. تهران. }
$$

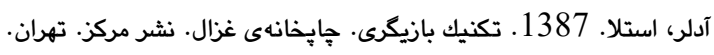

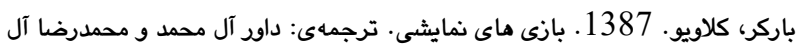

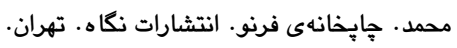

6. براهنى، رضا. 1368. قصه نويسى. جֶإخانه كتيبه. نشر البرز. تهران.

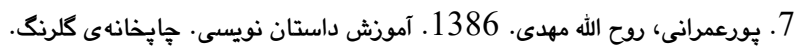

$$
\text { انتشارات تيركان. تهران. }
$$

تامس، جيمز . 1387. تحليل (فرماليستى) متن نمايشى: براى بانى بازيكران،

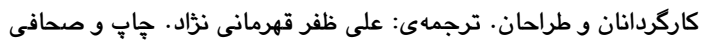

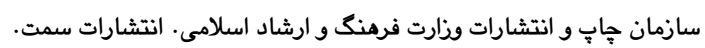
تهران.

جمعى از مؤلفان. 1386. روان شناسى عمومى. جاب و نشر دانشكاه بِيام نور. تهران.

حنيف، محمد. 1384. قابليتهاى نمايشى شاهنامه. هإِخانهى انتشارات سروش.

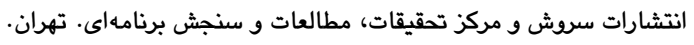
داد، سيما ـ 1385. فرهنگ اصطلاحات ادبى. جإِ ديدآور، انتشارات مرواريد. تهران. دورومى يى، ذاكلين. 1386. تراذدى يونان. ترجمهى: خسرو سميعى. جإِخانهى نيكا. نشر قطره. تهران. رضايى، عربعلى. 1382. وازگكان توصيفى ادبيات: انكليسى ـ فارسى. جإِخانهى واحد كاميِيوتر فرهنگ معاصر. انتشارات فرهنك معاصر. تهران.

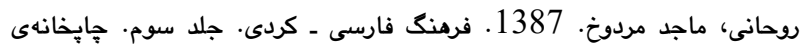

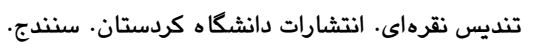
زرين كوب، دكتر عبدالحسين. 1376. آشنايى با نقد ادبى. جإِخانهى مهارت. انتشارات سخن. تهران.

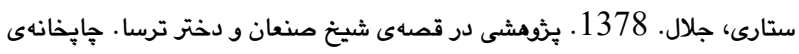
سعدى. نشر مركز. تهران. شميسا، دكتر سيروس. 1383. نقد ادبى. حإخانهى رامين. انتشارات فردوس. تهران. شواليه، ذان و كربران، آلن. 1385. فرهنگ نمادها. ترجمهى: سودابه فضايلى. جلد جهارم. جاب و نشر انتشارات جيحون. تهران. فرويد، زيكموند. 1342. تعبير خواب و بيماريهاى روانى. ترجمهى: ايرج بِ بورباقر. جإِخانهى فردوسى. مؤسسهى انتشارات آسيا. تهران.

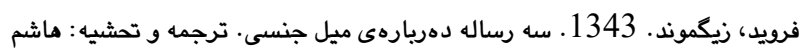
رضى. جإِخانهى كاويان. مؤسسهى انتشارات آسيا. تهران. 
تجسيد عنصر صراع القوات المتضاد الدرامي في ملحمة "شيخ الصنعاني" للشاعر (فقه الطيران) ـ انواع الأنسان ضد نفسه والأنسان ضد الأنسان أنموذجاً -ـ

\title{
Embodiment of Dramatic Contradicted-Power Conflict in Faqe Tayran's Epic Poem "Shekhe San'an - Man vs. self, man vs. man as a simple -
}

\begin{abstract}
:
Faqe Tayran's epic of Shekhe San'an, as an epic of Kurdish classic literature, has a lot of dramatic characteristics via which the bases of many dramatic techniques and types can be identified. Dramatic conflict which is regarded as the essence of drama without which the dramatic text loses its effectiveness, interest and taste and is dull. The dramatic nature of this epic allows one to be able to handle it as a dramatic text, especially because the dramatic conflict is powerfully manifested in this epic. Dramatic conflict according to its nature, concept and state is divided into some types: the general one, the concept of embodied conflict, the type of conflict and antagonism. In this study, antagonism is adopted because this type of dramatic conflict is in conformity with the nature and content of this epic more than do the other types. Therefore, this study is entitled "Embodiment of Dramatic Contradicted-Power Conflict in Faqe Tayran's Epic Poem "Shekhe San'an - Man vs. self, man vs. man as a simple -"
\end{abstract}

Keywords: Shekhe San'an, Dramatic conflict, Types of conflict, Man vs. self, man vs. man. 